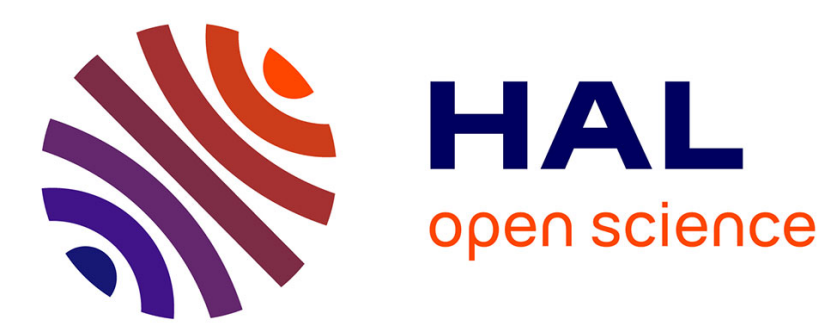

\title{
TELOMERIZATION OF \\ 3,3,3-TRIFLUOROPROP-1-ENE AND FUNCTIONALIZATION OF ITS TELOMERS
}

Georges Kostov, Bruno Ameduri, Stephan M. Brandstadter

\section{- To cite this version:}

Georges Kostov, Bruno Ameduri, Stephan M. Brandstadter. TELOMERIZATION OF 3,3,3TRIFLUOROPROP-1-ENE AND FUNCTIONALIZATION OF ITS TELOMERS. Collection of Czechoslovak Chemical Communications, 2008, 73 (12), pp.1747-1763. 10.1135/cccc20081747 . hal00353663

\section{HAL Id: hal-00353663 https://hal.science/hal-00353663}

Submitted on 16 Jan 2009

HAL is a multi-disciplinary open access archive for the deposit and dissemination of scientific research documents, whether they are published or not. The documents may come from teaching and research institutions in France or abroad, or from public or private research centers.
L'archive ouverte pluridisciplinaire HAL, est destinée au dépôt et à la diffusion de documents scientifiques de niveau recherche, publiés ou non, émanant des établissements d'enseignement et de recherche français ou étrangers, des laboratoires publics ou privés. 


\section{TELOMERIZATION OF 3,3,3-TRIFLUOROPROP-1-ENE AND FUNCTIONALIZATION OF ITS TELOMERS}

George K. Kostov ${ }^{1 *}$, Bruno Ameduri ${ }^{1 *}$, Stephan Brandstadter ${ }^{2}$

${ }^{1}$ Institut Charles Gerhardt, UMR CNRS 5253, Laboratoire « Ingénierie \& Architectures Macromoléculaires», Ecole Nationale Supérieure de Chimie de Montpellier, 8, Rue de l’Ecole Normale, 34296 Montpellier Cedex 5, France ; georges.kostov@enscm.fr; bruno.ameduri@enscm.fr.

${ }^{2}$ Great Lakes-Chemtura, P.O. Box 2200, West Lafayette, IN 47996-2200, USA;

stephan.brandstadter@chemtura.com

(Dedicated to our friend Prof. Oldrich Paleta on the occasion of his 70th birthday in recognition of his outstanding contributions to the area of organofluorine chemistry)

\section{SUMMARY}

The synthesis of four 3,3,3-trifluoroprop-1-ene telomers $\left(\mathrm{R}_{\mathrm{F}}-\left(\mathrm{C}_{3} \mathrm{H}_{3} \mathrm{~F}_{3}\right)_{\mathrm{n}} \mathrm{I}, \mathrm{n}=1,2, \mathrm{R}_{\mathrm{F}}=\right.$ $n-\mathrm{C}_{6} \mathrm{~F}_{13}-$ or $\left.\left(\mathrm{CF}_{3}\right)_{2} \mathrm{CF}-\right)$ and their allyl derivatives $\mathrm{R}_{\mathrm{F}}-\left(\mathrm{C}_{3} \mathrm{H}_{3} \mathrm{~F}_{3}\right)_{n} \mathrm{CH}_{2} \mathrm{CH}=\mathrm{CH}_{2}$ are presented. The allyl telomers were prepared by a three-step reaction. The first step involved the thermal and peroxide- induced bulk telomerization of 3,3,3-trifluoroprop1-ene (TFP) with heptafluoro-2-iodopropane or tridecafluoro-6-iodohexane leading to monoadduct and diadduct, the ratio of which depends on the $R_{0}=\left[\mathrm{R}_{\mathrm{F}} \mathrm{I}\right]_{0} /[\mathrm{TFP}]_{0}$ initial molar ratio and the reaction temperature. The amount of monoadduct increased up to $50-60 \%$ and of the diadduct to $25-30 \%$ at temperatures up to $180{ }^{\circ} \mathrm{C}$ (thermal-initiated) and $150{ }^{\circ} \mathrm{C}$ (initiated with di-tert-butyl peroxide, DTBP), $R_{0}$ up to 1.5 . It was observed that the addition of the $\left(\mathrm{CF}_{3}\right)_{2} \mathrm{CF}^{\bullet}$ radical onto the $=\mathrm{CH}_{2}$ of TFP was regioselective 
leading to selective formation of a single isomer in contrast to the addition of the $n$ $\mathrm{C}_{6} \mathrm{~F}_{13} \cdot$ radical. Then, the telomers reacted with allyl acetate yielding $\mathrm{R}_{\mathrm{F}}\left(\mathrm{C}_{3} \mathrm{H}_{3} \mathrm{~F}_{3}\right){ }_{n} \mathrm{CH}_{2} \mathrm{CH}(\mathrm{I}) \mathrm{CH}_{2} \mathrm{OCOCH}_{3}(\mathrm{n}=1,2$ ) in $50-80 \%$ yields. The third step consisted of a deiododeacetatization of these iodo-acetates into $\mathrm{R}_{\mathrm{F}}-\left(\mathrm{C}_{3} \mathrm{H}_{3} \mathrm{~F}_{3}\right)_{\mathbf{n}} \mathrm{CH}_{2}-$ $\mathrm{CH}=\mathrm{CH}_{2}(\mathbf{C}, \mathrm{n})$ giving $50-80 \%$ yields. All the intermediates were characterized by ${ }^{1} \mathrm{H}$, ${ }^{19} \mathrm{~F}$ and products by ${ }^{13} \mathrm{C}$ NMR spectroscopy.

KEY WORDS: 3,3,3-trifluoroprop-1-ene; Radical addition; Perfluoroalkyl iodides; Thermal and peroxide telomerisation; fluoroallylic monomer; ${ }^{1} \mathrm{H},{ }^{19} \mathrm{~F}$ and ${ }^{13} \mathrm{C}$ NMR spectroscopies.

\section{I.INTRODUCTION}

Telomerization of 3,3,3-trifluoroprop-1-ene (TFP) with various transfer agents was pioneered by Haszeldine after its synthesis in 1951 by dehydroiodination of

$\mathrm{CF}_{3} \mathrm{CH}_{2} \mathrm{CH}_{2} \mathrm{I}{ }^{1-3}$ (Table 1). Various ways of initiating the telomerization were investigated. The photochemical or thermal addition of $\mathrm{HBr}$ or $\mathrm{CF}_{3} \mathrm{I}$ to TFP yielded exclusively $\mathrm{CF}_{3} \mathrm{CH}_{2} \mathrm{CH}_{2} \mathrm{Br}$ or $\mathrm{CF}_{3}\left[\mathrm{CH}_{2} \mathrm{CH}\left(\mathrm{CF}_{3}\right)\right]_{\mathrm{n}} \mathrm{CH}_{2} \mathrm{CHICF}_{3}$, respectively. Low et al. ${ }^{4}$ investigated this reaction under UV radiation at various temperatures and obtained a mixture of normal and reverse isomers for the monoadduct. They observed that a higher proportion of products of reverse addition was formed at higher temperatures and the formation of higher adducts at ca. $175^{\circ} \mathrm{C}$. In addition for other transfer agents, diiodoperfluoroalkanes, silanes, phosphonates, disulfides react with TFP, yielding the monoadduct predominantely (Table 1$)^{5-12}$. 


\section{Insert Table 1}

Pertinent studies of TFP telomerization were performed by Russian teams using initiation with a peroxide or $\gamma$-rays (Table 1). Terentev et al. ${ }^{9}$ studied the cotelomerization of TFP with 2-methyl-1,3-dioxolane and obtained cyclic telomers accompanied by rearrangement of transient radical intermediates by $1,5-\mathrm{H}$ migration. Zamislov et al. ${ }^{13}$ used $\mathrm{C}_{1}-\mathrm{C}_{4}$ alcohols as telogens in TFP telomerization under $\gamma$ irradiation to get different fluoroalcohols. Vassileva et al. ${ }^{14-19}$ used different telogens such as $\mathrm{C}_{6} \mathrm{H}_{5} \mathrm{CH}_{2} \mathrm{Cl}, \mathrm{CBr}_{4}, \mathrm{CHBr}_{3}, \mathrm{CH}_{2} \mathrm{Br}_{2}$ (but not $\mathrm{CHCl}_{3}$ and $\mathrm{CBrCl}_{3}$ ) with the initiating system $\mathrm{Fe}(\mathrm{CO})_{5}$ - DMF or hexamethylphosphoramide (HMPA) (Table 1). In the presence of $\mathrm{Fe}(\mathrm{CO})_{5}-\mathrm{DMF}$, a radical mechanism was proved to take place and chain transfer constants of the telogens involved in telomerizations were determined. Keim et al. ${ }^{16}$ studied the transition-metal-catalyzed C-C coupling reaction of TFP with $\mathrm{CCl}_{4}$ in the presence of copper salts and obtained new telomers.

Systematic studies of telomerization reactions of fluorinated monomers, in particular fluoroalkenes, with various transfer agents were performed by Ameduri and Boutevin, published in several papers ${ }^{20}$ and more recently collected in a book ${ }^{21}$.

Two patents ${ }^{22,23}$ of Pennsalt Chem. Corp. claim the production of fluorinated organic telomers by heating at $150-250{ }^{\circ} \mathrm{C}$ unsaturated fluorinated compounds with an $\mathrm{R}_{\mathrm{F}} \mathrm{X}$ telogen, where $\mathrm{R}_{\mathrm{F}}$ and $\mathrm{X}$ are a perfluoroalkyl group and a halogen ( $\mathrm{Br}$ or $\left.\mathrm{I}\right)$, respectively. The degree of telomerization of the halogen-containing low-molecularweight linear telomers ranged from 3 to 7 . Rondestvedt ${ }^{24}$ described the preparation of perfluoroalkyl iodide telomers with a general formula $\mathrm{R}_{\mathrm{F}}\left[\mathrm{C}\left(\mathrm{R}^{1}\right)_{2} \mathrm{CR} \mathrm{R}^{2}\right]_{7} \mathrm{I}$ where $\mathrm{R}^{1}$ is $\mathrm{H}$ or $\mathrm{F}, \mathrm{R}^{2}$ is $\mathrm{H}, \mathrm{F}$ and $\mathrm{R}_{\mathrm{F}}$ represents a perfluoroalkyl group containing 2-22 carbon atoms. A Japanese patent ${ }^{25}$ claimed the synthesis of fluoroalkyl iodide telomers 
$\mathrm{C}_{\mathrm{n}} \mathrm{F}_{2 \mathrm{n}+1}\left(\mathrm{CR}^{1} \mathrm{R}^{2} \mathrm{CRR}^{1}\right)_{\mathrm{m}} \mathrm{I}$ where $\mathrm{R}=\mathrm{H}$, alkyl, $\mathrm{R}^{1}=\mathrm{H}$, halogen, $\mathrm{m}=2-6, \mathrm{n}=3-20$, but the produced telomers were not characterized.

The aim of this work is to synthesize and to characterize 3,3,3 - trifluoroprop-1-ene telomers (mostly mono- and diadducts) with perfluoroalkyl iodides $\mathrm{R}_{\mathrm{F}} \mathrm{I}\left(\mathrm{R}_{\mathrm{F}}=n-\mathrm{C}_{6} \mathrm{~F}_{13}\right.$ or $\left.\left(\mathrm{CF}_{3}\right)_{2} \mathrm{CF}\right)$ and their further modification to obtain new highly fluorinated monomers. The structure of the synthesized products, their main properties and telomerization mechanism were also studied.

\section{II.RESULTS AND DISCUSSION}

\section{II-1) Telomerization of 3,3,3-trifluoroprop-1-ene (TFP)}

Any radical telomerization requires radicals; in this study, the TFP telomerization involves various initiating systems (thermal, photochemical (UV), radical, metal complexes) and a perfluoroalkyl iodide $\mathrm{R}_{\mathrm{F}} \mathrm{I}$ (preferably $n-\mathrm{C}_{6} \mathrm{~F}_{13} \mathrm{I}$ and $\mathrm{i}-\mathrm{C}_{3} \mathrm{~F}_{7} \mathrm{I}$ ) as the telogen (or chain-transfer agent) as shown in Scheme 1.

$$
\mathrm{R}_{\mathrm{F}}-\mathrm{I}+\mathrm{n} \mathrm{CH}_{2}=\underset{\mathrm{CF}_{3}}{\mathrm{H}} \stackrel{\mathrm{In}}{\longrightarrow} \mathrm{R}_{\mathrm{F}}\left(\mathrm{CH}_{2} \underset{\mathrm{CF}_{3}}{\mathrm{C}} \underset{\mathrm{n}}{\mathrm{H}} \mathrm{I} \quad(\mathrm{n}=1,2)\right.
$$

\section{A,n}

Scheme1. Radical telomerization of 3,3,3-trifluoroprop-1-ene (TFP) with perfluoroalkyl iodide

Furthermore, the photochemical reaction and reactions of metal- complexes were carried out in batch conditions in Carius tubes. Thermal and peroxide initiations were carried out under pressure, in autoclave; at temperature ranging from 60 to $180{ }^{\circ} \mathrm{C}$ depending on the initiators used (the reaction temperature was chosen as a temperature of which their half-life was close to $1 \mathrm{~h}$ ). The initial telogen $[\mathrm{T}]_{0} /$ monomer $[\mathrm{M}]_{0}$ molar 
ratio $\left(R_{0}\right)$ varied from 0.25 to 1.50 and the reaction time ranged from 4 to $22 \mathrm{~h}$. The main results are displayed in Table 2.

(Insert Table 2)

The product mixture was analyzed by GC and, after distillation, the fractions were characterized by ${ }^{1} \mathrm{H},{ }^{19} \mathrm{~F}$ and ${ }^{13} \mathrm{C}$ NMR. The yield of mono- $(\mathrm{n}=1)$ and diadducts $(\mathrm{n}=2)$, of normal and reverse-addition product ratios as a function of reaction conditions are also shown in Table 2.

The most suitable initiators were: di-tert-butyl peroxide (DTBP) and 2,5-bis(tertbutylperoxy)-2,5-dimethylhexane (Trigonox101). The yields (Y) of the diadducts were higher than $65 \%$ for $R_{0}=0.5$ and of monoadducts higher than $50 \%$ for $R_{0}=1.4$.

The structure of the telomers and the mechanism of radical telomerization of TFP were proved by NMR analysis. The NMR characteristics are detailed in the Experimental part. ${ }^{19} \mathrm{~F}$ NMR spectrum of $n-\mathrm{C}_{6} \mathrm{~F}_{13}\left[\mathrm{CH}_{2}-\mathrm{CH}\left(\mathrm{CF}_{3}\right)\right] \mathrm{I}$ as an example of monoadduct is shown in Fig.1.

\section{(Insert Figure 1)}

There was no signal at $-59 \mathrm{ppm}$, assigned to $\mathrm{CF}_{2} \mathrm{I}$ end-group of the reacted telogen. Two peaks were observed in the range from -67 to $-72 \mathrm{ppm}$. The first one, at $-67.2 \mathrm{ppm}$ (b, $\mathrm{CF}_{3}$ of TFP), is related to the reverse addition (only $4.5 \mathrm{~mol} \%$ ). The major product (a, $\mathbf{C F}_{3}$ of TFP at $-70.2 \mathrm{ppm}$ ) has a structure with a normal addition (95.5 mol \%). All other signals are assigned to the $n-\mathrm{C}_{6} \mathrm{~F}_{13}$ group of the telogen. The expected signal at $-81.5 \mathrm{ppm}(\mathrm{t}, J=9.5 \mathrm{~Hz})$ is assigned to the $\alpha \mathrm{CF}_{3}$ of $n-\mathrm{C}_{6} \mathrm{~F}_{13}$. The other signals are: $\lambda\left(-113.7, \mathrm{~m}, \mathrm{CF}_{2} \mathrm{CH}_{2}\right), \varepsilon\left(-121.6 \mathrm{ppm}, \mathrm{CF}_{2} \mathrm{CF}_{2} \mathrm{CH}_{2}\right), \delta\left(-122.8, \mathrm{~m}, \mathrm{C}_{2} \mathrm{~F}_{5} \mathrm{CF}_{2} \mathrm{CF}_{2}\right)$, $\gamma\left(-123.6, \mathrm{~m}, \mathrm{C}_{2} \mathrm{~F}_{5} \mathrm{CF}_{2}\right)$ and $\beta\left(-126.6, \mathrm{~m}, \mathrm{CF}_{3} \mathrm{CF}_{2}\right)$. 
The ${ }^{1} \mathrm{H}$ NMR spectra of both monoadducts show the presence of the characteristic quintet of the AB-X system: $4.8 \mathrm{ppm}, \mathrm{C} * \mathbf{H}-,{ }^{3} J_{\mathrm{HF}}={ }^{3} J_{\mathrm{HHA}} \sim 15 \mathrm{~Hz} ;{ }^{3} J_{\mathrm{HHB}}=7 \mathrm{~Hz}$ and a multiplet at 3.25-2.65 ppm, centered at $2.9 \mathrm{ppm}\left(\mathrm{m}, \mathbf{H}_{\mathrm{A}}, \mathbf{H}_{\mathrm{B}}\right.$ in $\mathrm{AB}$ system $\left.\mathrm{R}_{\mathrm{F}} \mathrm{CH} \mathbf{H}_{2}\right)$. In addition, the ${ }^{13} \mathrm{C}$ NMR spectrum exhibits a quartet at $133.35,127.88,122.41,116.93$ ppm, assigned to $\mathrm{CF}_{3}\left({ }^{1} J_{\mathrm{CF}}=275.4 \mathrm{~Hz}\right)$ and a triplet at $36.59,36.17,35.75 \mathrm{ppm}$ for $\mathrm{CH}_{2}$ of TFP $\left({ }^{3} J_{\mathrm{CF}}=20.8 \mathrm{~Hz}\right)$. The quartet with negative intensity at $7.07,6.42,5.74,5.06$ ppm is assigned to asymmetric carbon $\mathbf{C}^{*} \mathrm{H}\left({ }^{2} J_{\mathrm{CF}}=33.5 \mathrm{~Hz}\right)$ while that at $-15.3 \mathrm{ppm}$ is related to a reverse addition product $(\sim 3.0 \mathrm{~mol} \%)$ of the $\mathrm{CH}_{2}-\mathrm{I}$ terminal group. Interestingly, the reverse monoadduct was not produced from $\mathrm{i}-\mathrm{C}_{3} \mathrm{~F}_{7} \mathrm{I}$ giving a more electrophilic and bulky perfluoroisopropyl radical, which hence reacted selectively at the $\mathrm{CH}_{2}$ of TFP (more "nucleophilic" and less hindered than the $=\mathrm{CH}$ site).

The NMR spectra of TFP diadducts of the $n-\mathrm{C}_{6} \mathrm{~F}_{13} \mathrm{I}$ telogen and those of $\left(\mathrm{CF}_{3}\right)_{2} \mathrm{CFI}$ are described in Experimental part (Runs 2, 7 and 8, Table 3) and DEPT ${ }^{13} \mathrm{C}$ NMR spectrum of $\left(\mathrm{CF}_{3}\right)_{2} \mathrm{CFCH}_{2}-\mathrm{CH}\left(\mathrm{CF}_{3}\right) \mathrm{I}$ monoadduct is illustrated in Fig. 2.

(Insert Figure 2)

\section{Mechanism of TFP telomerization}

Two alternatives of the the mechanism can be proposed: the first one is the classical mechanism of telomerization in which the $\mathrm{R}_{\mathrm{F}} \mathrm{CH}_{2}-\mathrm{CH}\left(\mathrm{CF}_{3}\right)^{\bullet}$ radical produced may undergo either telogen transfer or initiate the propagation of TFP. In the latter case, the reverse addition product can be formed in the propagation step (Scheme 2).

(Insert Scheme 2)

However, a stepwise mechanism may operate in which $\mathrm{R}_{\mathrm{F}} \mathrm{CH}_{2}-\mathrm{CH}\left(\mathrm{CF}_{3}\right) \mathrm{I}$ formed by $\mathrm{R}_{\mathrm{F}} \mathrm{I}$ transfer acts as a telogen in further telomerization of TFP as shown in Scheme 2. 


\section{II-2) Synthesis of iodo-acetate compounds of TFP telomers, $\mathrm{R}_{\mathrm{F}}\left[\mathrm{CH}_{2}-\mathrm{CH}\left(\mathrm{CF}_{3}\right)\right]_{\mathrm{n}} \mathrm{I}$,} $n=1,2$.

This type of reactions was studied earlier ${ }^{26}$ and more recently described ${ }^{27}$. Various peroxides such as dibenzoyl peroxide, tert-pentyl peroxypivalate, DTBP, AIBN, etc. can be used. Because of the great exothermicity of the reaction, the initiator used was of high importance; its activity is associated with its low decomposition temperature. It was previously observed that when the starting temperature was higher than $90{ }^{\circ} \mathrm{C}$ (e.g. , when initiated with dibenzoyl peroxide) the reaction temperature rose to $160-180{ }^{\circ} \mathrm{C}$ and at such high temperature the produced $\omega$-perfluoroiodoacetate undergoes a thermal rearrangement to $\mathrm{R}_{\mathrm{F}} \mathrm{CH}_{2} \mathrm{CH}(\mathrm{OAc}) \mathrm{CH}_{2} \mathrm{I}^{26,28}$.

To avoid such an undesired transformation, we chose AIBN as the initiator added ${ }^{27}$. In this case, no exotherm was observed and the GC yield increased up to $80-82 \mathrm{wt} \%$ or 75 wt $\%$ after distillation.

$$
\left.\mathbf{A , n}+\mathrm{CH}_{2}=\mathrm{CHCH}_{2} \mathrm{OAc} \frac{\mathrm{AIBN}}{82^{\circ} \mathrm{C}, 10 \mathrm{~h}} \mathrm{R}_{\mathrm{F}}-\underset{\mathrm{CF}_{3}}{\mathrm{CH}-\mathbf{n}} \underset{\mathrm{I}}{\mathrm{CH}}\right)_{\mathrm{n}} \mathrm{CH}_{2} \underset{\mid}{\mathrm{CH}}-\mathrm{CH}_{2} \mathrm{OCOCH}_{3}
$$

Scheme 3.Radical addition of TFP telomers onto allyl acetate The main results are presented in Table 3.

\section{(Insert Table 3)}

The structure of different iodo-acetates was studied by ${ }^{1} \mathrm{H}$ and ${ }^{19} \mathrm{~F}$ NMR spectroscopy (Runs 3, 4, 9, 10 in Experimental part). The signals at $4.2 \mathrm{ppm}$ are assigned to protons of $\mathrm{CH}_{2} \mathrm{OAc}$ groups of normal structure. However, the rearranged iodo-acetate (the signal of CHOAc at $5.10 \mathrm{ppm}$ ) was not observed. The multiplet at 4.3-4.5 ppm is related to the $\mathrm{CHI}$ group, the multiplet of $\mathrm{CH}_{2} \mathrm{CHI}$ at 2.1-2.2 ppm and a singlet at 2.02 
ppm is attributed to $\mathrm{CH}_{3}$ of the acetate. The other signals at 2.25-2.60 ppm (m, $\left.\mathrm{CFCH}_{2}\right)$ and at 2.8-3.1 $\mathrm{ppm}\left(\mathrm{m},{ }^{*} \mathrm{CH}\left(\mathrm{CF}_{3}\right)\right)$ are assigned to TFP protons.

For the diadduct, $1 \mathrm{H}$ NMR spectra are more complex due to a new multiplet in the range of 1.6-1.9 $\mathrm{ppm}\left({ }^{*} \mathrm{C}-\mathrm{CH}_{2}-\mathrm{C}^{*}\right)$.

The ${ }^{19} \mathrm{~F}$ NMR spectra are similar to those of the starting telomers.

\section{II-3) Synthesis of fluoroallylic monomers $\mathrm{CH}_{2}=\mathrm{CH}-\mathrm{CH}_{2}\left(\mathrm{C}_{3} \mathrm{H}_{3} \mathrm{~F}_{3}\right)_{\mathrm{n}} \mathrm{R}_{\mathrm{F}}$}

As described previously ${ }^{27-29}$, fluorinated allyl monomers $\mathbf{C}, \mathrm{n}$ can be obtained by deiododeacetatization reaction from B,n (Scheme 4)

$$
\text { B,n } \underset{\text { reflux, } 5 \mathrm{~h}}{\stackrel{\mathrm{Zn} / \mathrm{CH}_{3} \mathrm{OH}}{\longrightarrow}} \mathrm{CH}_{2}=\mathrm{CH}-\mathrm{CH}_{2}\left(\underset{\substack{\mathrm{CF}_{3} \\ \mathbf{C , n}}}{\mathrm{CH}}-\mathrm{CH}_{2} \frac{1}{\mathrm{n}} \mathrm{R}_{\mathrm{F}}\right.
$$

Scheme 4. Synthesis of fluorinated allylic monomers based on TFP

The iodo-acetate B,n was added to a two-fold excess of activated $\mathrm{Zn}$ in $\mathrm{MeOH}$. The reaction was rather exothermic and was monitored by GC. The conversion of $\mathbf{B , n}$ was complete. The overall yield of the reaction product $\mathbf{C , n}$ was close to $75 \%$ after distillation.

Both allylic monomers with $n-\mathrm{C}_{6} \mathrm{~F}_{13}$ or $\left(\mathrm{CF}_{3}\right)_{2} \mathrm{CF}$ groups were characterized by ${ }^{1} \mathrm{H}$ and ${ }^{19} \mathrm{~F}$ NMR spectroscopies. The ${ }^{1} \mathrm{H}$ NMR spectrum of $\left(\mathrm{CF}_{3}\right)_{2} \mathrm{CFCH}_{2}-\mathrm{CH}\left(\mathrm{CF}_{3}\right)$ $\mathrm{CH}_{2} \mathrm{CH}=\mathrm{CH}_{2}$ exhibits two multiplets in the 5.0-5.4 ppm and at 5.6-5.9 ppm regions, assigned to the protons of the double bond $\mathrm{CH}=\mathrm{CH}_{2}$ and $\mathrm{CH}_{2}=\mathrm{CH}$ (Fig. 3). The multiplet at 2.6-3.0 ppm is related to the proton of asymmetric carbon, ${ }^{*} \mathrm{CH}\left(\mathrm{CF}_{3}\right)$ and that at 2.2-2.6 ppm to both methylene protons of the $\mathrm{CH}_{2} \mathrm{CH}=\mathrm{CH}_{2}$ and $\mathrm{CFCH}_{2}$ structures. 


\section{(Insert Figure 3)}

The ${ }^{13} \mathrm{C}$ NMR spectrum also confirms the structure of the allylic monomers. Hence, the signals at $132.2 \mathrm{ppm}(=\mathbf{C H}, 1 \mathrm{C})$ and $119.4 \mathrm{ppm}\left(\mathrm{s}, \mathrm{CH}=\mathbf{C H}_{2}, 1 \mathrm{C}\right)$ are assigned to both carbon atoms of the double bond. Both quartets centered at 128 and $120 \mathrm{ppm}$ are assigned to $\mathbf{C F}_{3^{-}}$of TFP $\left({ }^{1} J_{\mathrm{CF}}=279.7 \mathrm{~Hz}\right)$ and $\left(\mathbf{C F}_{3}\right)_{2}$ of telogen $\left({ }^{1} J_{\mathrm{CF}}=284.7 \mathrm{~Hz}\right.$, $\left.{ }^{2} J_{\mathrm{CF}}=27.2 \mathrm{~Hz}\right)$, respectively. The doublet $\left({ }^{1} J_{\mathrm{CF}}=206.3 \mathrm{~Hz}\right)$ of septuplet $\left({ }^{2} J_{\mathrm{CF}}=32.0 \mathrm{~Hz}\right)$ centered at $90 \mathrm{ppm}$ is characteristic of the $\mathbf{C F}$ group adjacent to both $\mathrm{CF}_{3}$ end-groups while the quartet $\left({ }^{2} J_{\mathrm{CF}}=27.2 \mathrm{~Hz}\right)$ centered at $37.1 \mathrm{ppm}$ is assigned to $* \mathbf{C H}\left(\mathrm{CF}_{3}\right)$ group. The other signals are characteristic of the allyl carbon atoms with the doublet of $\mathrm{CFCH}_{2},\left({ }^{2} J_{\mathrm{CF}}=19.1 \mathrm{~Hz}\right)$ at $25.5 \mathrm{ppm}$. Of course, the ${ }^{13} \mathrm{C}$ NMR spectra of diadducts are more complex (see Experimental part). The ${ }^{19} \mathrm{~F}$ NMR spectra are similar to those of corresponding telomers and some of them were already discussed. The details of these spectra are presented in Experimental.

\section{III.CONCLUSION}

This work described the synthesis of four new highly fluorinated telomers based on 3,3,3-trifluoroprop-1-ene ( $\mathrm{n}=1$ and 2 ) and their functionalization to obtain allylic monomers containing TFP unit(s), by a three step-reaction for further applications. The first step involved a simple bulk addition of perfluoroalkyl iodide $\mathrm{R}_{\mathrm{F}} \mathrm{I}\left(\mathrm{R}_{\mathrm{F}}=n-\mathrm{C}_{6} \mathrm{~F}_{13}\right.$ or i- $\mathrm{C}_{3} \mathrm{~F}_{7}$ ) onto TFP and showed that DTBP at $150{ }^{\circ} \mathrm{C}$ was a suitable initiator to get $50-60$ $\%$ yield for $\mathrm{n}=1$ or 2 depending on the $R_{0}$ ratio. For $n-\mathrm{C}_{6} \mathrm{~F}_{13} \mathrm{I}$ as the telogen, both normal and reverse additions took place, but no reverse addition product was obtained with i- $\mathrm{C}_{3} \mathrm{~F}_{7} \mathrm{I}$. The second step involved radical addition of $\mathrm{R}_{\mathrm{F}}\left(\mathrm{C}_{3} \mathrm{H}_{3} \mathrm{~F}_{3}\right)_{n} \mathrm{I}$ onto allyl acetate using AIBN initiator added portionwize. The thermal rearrangement was not observed, 
and the yield was satisfactory $(50-80 \%)$. In the third step, the deiododeacetatization took place to produce allylic fluorine-containing monomer in $50-80 \%$ yield. All the

compounds synthesized were characterized by $\mathrm{GC}$ and ${ }^{1} \mathrm{H},{ }^{19} \mathrm{~F}$, and ${ }^{13} \mathrm{C} \mathrm{NMR}$ spectroscopies. The obtained products could be suitable intermediates in preparation of new fluorinated products utilized as coating materials, surfactants, block copolymers, hybrid fluorosilicones.

\section{IV.EXPERIMENTAL}

\section{IV-1) Reactants}

3,3,3-trifluoroprop-1-ene (TFP) and heptafluoro-2-iodopropane $\left(\mathrm{i}-\mathrm{C}_{3} \mathrm{~F}_{7} \mathrm{I}\right)$ were kindly supplied by the Great Lakes Chemical Corporation (now Chemtura ,West Lafayette, IN., USA), tridecafluoro-6-iodohexane $\left(n-\mathrm{C}_{6} \mathrm{~F}_{13} \mathrm{I}\right)$ by Elf Atochem (Pierre Benite, France), 2,5-bis(tert-butylperoxy)-2,5-dimethylhexane (Trigonox101) by Akzo Nobel, acetonitrile by SDS, AIBN and di-tert-butyl peroxide (DTBP) by Aldrich, and were used as received.

\section{IV-2) Apparatus}

After reaction and evaporation of the solvent, the product mixture was analyzed by gas chromatography (GC) using a Delsi apparatus (model 330) equipped with a SE 30 column, $2 \mathrm{~m} \times 1 / 8$ in. (i.d.). The nitrogen pressure at the inlet of the column was maintained at 1 bar and the detector and injector temperatures were $240{ }^{\circ} \mathrm{C}$ and $235{ }^{\circ} \mathrm{C}$, respectively. The temperature programmer started from $50{ }^{\circ} \mathrm{C}$ and reached $200{ }^{\circ} \mathrm{C}$ at a heating rate of $10{ }^{\circ} \mathrm{C} / \mathrm{min}$. The GC apparatus was connected to a Hewlett Packard integrator (model 3390). 
The structures of the telomers were determined by NMR spectroscopy at room temperature. The ${ }^{1} \mathrm{H},{ }^{19} \mathrm{~F}$, and ${ }^{13} \mathrm{C}$ NMR spectra were recorded on a Bruker AC-250 or Bruker $400 \mathrm{MHz}$ instruments using deuterated chloroform or acetone and tetramethyl silane or $\mathrm{CFCl}_{3}$ as the solvent and internal references, respectively. The experimental conditions for recording ${ }^{1} \mathrm{H}$ (or ${ }^{19} \mathrm{~F}$ ) NMR spectra were the following : flip angle $90^{\circ}$ $\left(30^{\circ}\right)$; acquisition time $4.5 \mathrm{~s}(0.7 \mathrm{~s})$; pulse delay $2 \mathrm{~s}(5 \mathrm{~s}) ; 36(64)$ scans and pulse width $5 \mu$ s for ${ }^{19} \mathrm{~F}$ NMR. Abbreviations used: s- singlet, d- double, $\mathrm{t}$ - triplet, q- quartet, qn- quintet, sex- sextet; sept- septuplet; m- multiplet

er - erythro; tr -threo

\section{IV-3) Reactions}

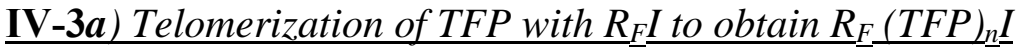

In a 160 or $500 \mathrm{~cm}^{3}$ Hastelloy autoclave equipped with a manometer, a magnetic stirrer, and safety valve, $\mathrm{R}_{\mathrm{F}} \mathrm{I}$ and the initiator (in amounts depending on initial molar ratios $R_{0}$ and $C_{0}$ ) were introduced and purged with $\mathrm{Ar}$ for $15 \mathrm{~min}$. The reactor was closed and checked for the leak at 30 bar of $\mathrm{N}_{2}$. The reactor was placed in acetone/liquid nitrogen to cool the contents. Then, 5-7 vacuum-Ar cycles were applied to remove oxygen from the liquid. The required amount of TFP, depending on the $R_{0}$ was condensed in the autoclave. The autoclave was heated up to $150{ }^{\circ} \mathrm{C}$ and the telomerization was carried out at $150 \pm 5^{\circ} \mathrm{C}$ for $4 \mathrm{~h}$. According to the TFP amount, the pressure was increased and pressure and temperature were recorded during the reaction. A sharp decrease in the pressure at almost constant temperature $\left(150{ }^{\circ} \mathrm{C}\right)$ for the first hour and then a small pressure change were observed. After the reaction stopped, the autoclave was cooled and then placed in an ice bath. The unreacted monomer was expelled by purging and the conversion of telomerization was determined by double weighing ( $90-95 \%)$. The 
crude product was analyzed by GC and then washed with a saturated solution of $\mathrm{Na}_{2} \mathrm{~S}_{2} \mathrm{O}_{5}$ in aqueous $\mathrm{NaOH}$ to remove the iodine produced. The reaction mixture was distilled to separate the adducts. The retention time (RT) and boiling point (b.p.) of the products are listed in Table 3 .

\section{Characteristics of the products}

Run 1, Table 3; Monoadduct: $n-C_{6} F_{13}\left(C_{3} H_{3} F_{3}\right)-I$;

2-iodo-2H,3H,3H-perfluorononane - normal adduct- $96 \%$,

1-iodo-1H,1H,2H-2-(trifluoromethyl)perfluorooctane- reverse adduct- $4 \%$.

${ }^{19}$ F NMR (acetone- $d_{6}$ ) (Fig. 1): $\delta$, ppm: -67.2 (b, CF 3 of TFP - reverse adduct) ; -70.2 (a, $\mathrm{CF}_{3}$ of TFP, normal adduct, $\left.3 \mathrm{~F}\right) ;-81.5\left(\mathrm{t}, J=9.5 \mathrm{~Hz}, \mathrm{CF}_{3}\right.$ of $\left.n-\mathrm{C}_{6} \mathrm{~F}_{13} \mathrm{I}, \alpha, 3 \mathrm{~F}\right) ;-113.7$ $\left(\mathrm{m}, \mathrm{CF}_{2} \mathrm{CH}_{2}, \lambda, 2 \mathrm{~F}\right) ;-121.6\left(\mathrm{~m}, \mathrm{CF}_{2} \mathrm{CF}_{2} \mathrm{CH}_{2}, \varepsilon, 2 \mathrm{~F}\right) ;-122.8\left(\mathrm{~m}, \mathrm{C}_{2} \mathrm{~F}_{5} \mathrm{CF}_{2} \mathrm{CF}_{2}, \delta, 2 \mathrm{~F}\right)$; $-123.6\left(\mathrm{~m}, \mathrm{C}_{2} \mathrm{~F}_{5} \mathrm{CF}_{2}, \gamma, 2 \mathrm{~F}\right) ;-126.6\left(\mathrm{~m}, \mathrm{CF}_{3} \mathrm{CF}_{2}, \beta, 2 \mathrm{~F}\right)$.

${ }^{1} \mathbf{H}$ NMR (acetone- $d_{6}$ ) $\delta$, ppm: 4.8 (qn, AB-X system, C ${ }^{*}-\mathbf{H},{ }^{3} J_{\mathrm{HF}}={ }^{3} J_{\mathrm{HHA}} \sim 15 \mathrm{~Hz}$; $\left.{ }^{3} J_{\mathrm{HHB}}=7 \mathrm{~Hz}\right), 3.25-2.65,2.9\left(\mathrm{~m}, \mathbf{H}_{\mathrm{A}}, \mathbf{H}_{\mathrm{B}}\right.$ in $\mathrm{AB}$ system $\left.\mathrm{R}_{\mathrm{F}} \mathrm{CH}_{2}, 2 \mathrm{H}\right)$.

${ }^{13}$ C NMR (acetone- $d_{6}$ ) $\delta$, ppm:133.35; $127.88 ; 122.41 ; 116.93\left(\mathrm{q}, \mathbf{C F}_{3},{ }^{1} J_{\mathrm{CF}}=275.4\right.$ $\mathrm{Hz}), 36.59 ; 36.17 ; 35.75\left(\mathrm{t}, \mathbf{C H}_{2},{ }^{3} J_{\mathrm{CF}}=20.8 \mathrm{~Hz}\right), 7.07 ; 6.42 ; 5.74 ; 5.06$ (q, negative intensity $\left.\mathbf{C}^{*} \mathrm{H},{ }^{2} J_{\mathrm{CF}}=33.5 \mathrm{~Hz}\right),-15.3\left(\mathbf{C H}_{2}-\mathrm{I}\right) \sim 2.5 \%$ reverse adduct.

Run 7, Table 3; Monoadduct: $\left(\mathrm{CF}_{3}\right)_{2} \mathrm{CF}\left(\mathrm{C}_{3} \mathrm{H}_{3} \mathrm{~F}_{3}\right)-\mathrm{I}$

2-iodo-2H,3H,3H-4-(trifluoromethyl)perfluoropentane

${ }^{19} \mathbf{F}$ NMR $\left(\mathrm{CDCl}_{3}\right) \delta$, ppm: $-71.3\left(\mathrm{~m}, \mathrm{CF}_{\mathbf{3}}\right.$ of TFP, $\left.3 \mathrm{~F}\right) ;-77.7$ and $-78.5\left[\mathrm{~d} \mathrm{t},\left(\mathrm{CF}_{3}\right)_{2}, 6 \mathrm{~F}\right)$, $-188.9(\mathrm{t}, \mathrm{CF}, 1 \mathrm{~F})$.

${ }^{1} \mathbf{H}$ NMR $\left(\mathrm{CDCl}_{3}\right) \delta$, ppm: 2.75-3.40 ( m, CH $\left.2,2 \mathrm{H}\right)$, 4.3-4.7 (m, *CH, 1H).

${ }^{13} \mathbf{C}$ NMR $\left(\mathrm{CDCl}_{3}\right)$ (Fig. 2): $\delta$, ppm : 132.1; 126.7; 121.2; 115.7; (q, $\mathbf{C F}_{3}$ of TFP, $\left.{ }^{1} J_{\mathrm{CF}}=275.6 \mathrm{~Hz}, 1 \mathrm{C}\right), \quad 129.2 ; 123.5 ; 117.9 ; 112.2\left[\mathrm{q}\right.$ of $\mathrm{d},\left(\mathrm{CF}_{3}\right)_{2-}, \quad{ }^{1} J_{\mathrm{CF}}=285.04 \mathrm{~Hz}$, 
${ }^{2} J_{\mathrm{CF}}=25.3 \mathrm{~Hz}, 2 \mathrm{C}$ ], 92.08-87.91 [dsept, $\mathbf{C}(\mathrm{F}),{ }^{1} J_{\mathrm{CF}}=210 \mathrm{~Hz},{ }^{2} J_{\mathrm{CF}}=32.5 \mathrm{~Hz}, 1 \mathrm{C}$ ], 33.6$33.2\left(\mathrm{~d}, \mathbf{C H}_{2}\right.$ of TFP, $\left.{ }^{2} J_{\mathrm{CF}}=17.8 \mathrm{~Hz}, 1 \mathrm{C}\right), 7.5 ; 6.8 ; 6.2 ; 5.5\left[\mathrm{q}, \mathbf{C H}\left(\mathrm{CF}_{3}\right),{ }^{2} J_{\mathrm{CF}}=33.0 \mathrm{~Hz}\right.$, $1 \mathrm{C}]$.

Run 2, Table 3; Diadduct: $n-C_{6} F_{13}\left(C_{3} H_{3} F_{3}\right)_{2}-I$ 
2-iodo-2H,3H,3H,4H,5H,5H-4-(trifluoromethyl)perfluoroundecanenormal adduct- $72 \%$;

1-iodo-1H,1H,2H,3H,4H,4H,-2,3-bis(trifluoromethyl)perfluorodecanereverse adduct- $28 \%$.

${ }^{19} \mathbf{F}$ NMR $\left(\mathrm{CDCl}_{3}\right) \delta$, ppm: $-68.8\left(\mathrm{~s}, \mathrm{CH}\left(\mathrm{CF}_{3}\right) \mathrm{I}\right.$-reverse, b , 3F $),-71.4\left(\mathrm{CH}_{2}-\right.$ $\mathrm{C}^{*} \mathrm{H}\left(\mathrm{CF}_{3}\right)-\mathrm{CH}_{2}$, normal, a , 3F) , -69.6 and - $72.2\left(\mathrm{C}^{*} \mathrm{H}\left(\mathrm{CF}_{3}\right)-\mathrm{C}^{*} \mathrm{H}\left(\mathrm{CF}_{3}\right), 6 \mathrm{~F}\right),-81.2(\mathrm{t}$, $\left.J=9.5 \mathrm{~Hz}, \alpha, \mathrm{CF}_{3}, 3 \mathrm{~F}\right),-113.7\left(\mathrm{~m}, \mathrm{CF}_{2} \mathrm{CH}_{2}, \lambda, 2 \mathrm{~F}\right),-121.6\left(\mathrm{~m}, \mathrm{CF}_{2} \mathrm{CF}_{2} \mathrm{CH}_{2}, \varepsilon, 2 \mathrm{~F}\right)$, $122.8\left(\mathrm{~m}, \mathrm{C}_{2} \mathrm{~F}_{5} \mathrm{CF}_{2} \mathrm{CF}, \delta, 2 \mathrm{~F}\right),-123.6\left(\mathrm{~m}, \mathrm{C}_{2} \mathrm{~F}_{5} \mathrm{CF}_{2}, \gamma, 2 \mathrm{~F}\right),-126.6\left(\mathrm{~m}, \mathrm{CF}_{3} \mathrm{CF}_{2}, \beta, 2 \mathrm{~F}\right)$ ${ }^{1} \mathbf{H}$ NMR $\left(\mathrm{CDCl}_{3}\right) \delta$, ppm: $2.18-2.28\left(\mathrm{t},{ }^{3} \mathrm{~J}_{\mathrm{HH}}=4.1 \mathrm{~Hz}\right), 2.29-2.33\left({ }^{3} J_{\mathrm{HH}}=6 \mathrm{~Hz}, \mathrm{C}^{*}-\mathrm{CH}_{2}-\right.$ $\mathrm{C}^{*}$, AB system, 2H), $2.5\left(\mathrm{td},{ }^{3} J_{\mathrm{HF}}=11 \mathrm{~Hz},{ }^{3} J_{\mathrm{HH}}=6 \mathrm{~Hz}, \mathrm{R}_{\mathrm{F}} \mathrm{CH}_{2}, 2 \mathrm{H}\right), 3.0-3.2\left(\mathrm{~m},{ }^{3} J_{\mathrm{HH}}=9\right.$ $\mathrm{Hz}, \mathrm{CH}_{2} \mathrm{I}$ reverse, $\left.2 \mathrm{H}\right), 4.4\left(\mathrm{~m}, 1 \mathrm{HH}_{\mathrm{A}}, 1 \mathrm{HH}_{\mathrm{B}} J=6.1 \mathrm{~Hz}, \mathrm{C}^{*} \mathbf{H}\left(\mathrm{CF}_{3}\right), 1 \mathrm{H}\right)$.

${ }^{13}$ C NMR $\left(\mathrm{CDCl}_{3}\right) \delta$, ppm: 130.7 (130.5); 127.9 (127.7); 125.2 (124.9); 122.4 (122.3) ( $\mathrm{q}$ of $\mathrm{d}$ (two stereoisomers), $\mathrm{CF}_{3}$ of TFP between two $\mathrm{CH}_{2}$ groups in the normal adduct, $\left.{ }^{1} J_{\mathrm{CF}}=279.4 \mathrm{~Hz}, 1 \mathrm{C}\right), 128.3(128.15) ; 125.6(125.4) ; 122.8(122.7) ; 120.1$ (119.9) ( q of $\mathrm{d}, \mathrm{CF}_{3}$ of TFP adjacent to I , ${ }^{1} J_{\mathrm{CF}}=275.9 \mathrm{~Hz}, 1 \mathrm{C}$ ) , 122-105 (complex system assigned to $\left.n-\mathrm{C}_{6} \mathrm{~F}_{13^{-}}\right), 37.32 ; 37.05 ; 36.77 ; 36.49 ; 36.21$ ( qn (er and tr), $\mathbf{C}^{*} \mathrm{H}\left(\mathrm{CF}_{3}\right)$ from the side of $\mathrm{R}_{\mathrm{F}},{ }^{2} J_{\mathrm{CF}}=27.6 \mathrm{~Hz}, 1 \mathrm{C}$ ), 35.83-35.40 (reverse, negligible), $1 * \mathrm{C}$ ), $33.88 ; 32.89$ (er./tr.), $\mathbf{C H}_{2}$ between two C*, 1 C), 29.97 (29.92) ; 29.75 (29.70) ; 29.54 (29.48); ( $\mathrm{t}$ of $\mathrm{d}(\mathrm{er} / \mathrm{tr}), \mathrm{R}_{\mathrm{F}}-\mathrm{CH}_{2},{ }^{2} J_{\mathrm{CF}}=20.9 \mathrm{~Hz}, 1 \mathrm{C}$ ), $19.94 ; 19.61 ; 17.24$ (two q, $\mathrm{C} * \mathrm{H}\left(\mathrm{CF}_{3}\right) \mathrm{I},{ }^{2} J_{\mathrm{CF}}=32.2 \mathrm{~Hz}, 1 \mathrm{C}$ ), $5.62-4.59$ (q of reverse adduct, negligible $\mathrm{CH}_{2} \mathrm{I}, 1 \mathrm{C}$ ). Run 8, Table 3; Diadduct: $\left(\mathrm{CF}_{3}\right)_{2} \mathrm{CF}\left(\mathrm{C}_{3} \mathrm{H}_{3} \mathrm{~F}_{3}\right)_{2}-\mathrm{I}$ 2-iodo-2H,3H,3H,4H,5H,5H,-4,6-bis(trifluoromethyl)perfluoroheptane-normal adduct 1-iodo-1H,1H,2H,3H,4H,4H,-2,3,5-tris(trifluoromethyl)perfluorohexane-reverse adduct 
${ }^{19} \mathbf{F}$ NMR $\left(\mathrm{CDCl}_{3}\right) \delta$, ppm : -69.6; -70.9; -71.5; -72.9 (assigned to $\mathrm{CF}_{\mathbf{3}}$ of both TFP (normal and reverse adducts, 6F) , -77.3; -78.5; -78.8 ( $\left(\mathrm{t},\left(\mathrm{CF}_{3}\right)_{2}, 6 \mathrm{~F}\right),-185.5 ;-187.2(\mathrm{dt}$ $\mathrm{C}(\mathbf{F}), 1 \mathrm{~F})$.

${ }^{1} \mathbf{H}$ NMR $\left(\mathrm{CDCl}_{3}\right) \delta, \mathrm{ppm}: 1.9-2.3\left(\mathrm{~m},{ }^{*} \mathrm{C}-\mathrm{CH}_{2}-\mathrm{C}^{*}, 2 \mathrm{H}\right), 2.3-2.7\left(\mathrm{~m}, \mathrm{R}_{\mathrm{F}}-\mathrm{CH}_{2}, 2 \mathrm{H}\right)$, 2.6-3.2 (m, ${ }^{*} \mathrm{CH}\left(\mathrm{CF}_{3}\right) 25 \%$ of one diastereoisomer overlapping with $\mathrm{R}_{\mathrm{F}}-\mathrm{CH}_{2}$ protons and $75 \%$ in the range of 2.75-3.2 ppm ; negligible reverse adduct (absence of signal at 3.5 ppm, 1H), 4.15-4.45 ( $\left.\mathrm{m},{ }^{*} \mathrm{CH}\left(\mathrm{CF}_{3}\right) \mathrm{I}, 1 \mathrm{H}\right)$.

${ }^{13} \mathbf{C}$ NMR $\left(\mathrm{CDCl}_{3}\right) \quad \delta$, ppm:130.8 (130.6) ; 128.0 (127.8) ; 125.2 (125.0) ; 122.4 (122.3); (q of $\mathrm{d}$ (coupling of two diastereoisomers) , $\mathrm{CF}_{3}$ of TFP between two $-\mathrm{CH}_{2}$ groups in normal adduct), $\left.{ }^{1} J_{\mathrm{CF}}=279.7 \mathrm{~Hz}, 1 \mathrm{C}\right) 128.4$ (128.16) ; 125.66 (125.42) ; $122.92(122.68) ; 120.18(119.94)\left(\mathrm{q}\right.$ of $\mathrm{d}, \mathrm{CF}_{3}$ adjacent to $\mathrm{I}$ in normal adduct, $\left.{ }^{1} J_{\mathrm{CF}}=276.7 \mathrm{~Hz}, 1 \mathrm{C}\right), 125.04(124.94) ; 122.27$ (122.10) ; 119.39 (119.26) ; 116.55 (116.43); 124.79 (124.66); 121.95 (121.82); 119.11 (118.99); 116.27 (116.15) ( two q of d, $\mathbf{C F}_{3},{ }^{1} J_{\mathrm{CF}}=285.7 \mathrm{~Hz},{ }^{2} J_{\mathrm{CF}}=28.17 \mathrm{~Hz}, 6 \mathrm{C}$ ), 92.63-89.02 (d of sept., C(F), ${ }^{1} J_{\mathrm{CF}}=207.3$ $\left.\mathrm{Hz} ;{ }^{2} J_{\mathrm{CF}}=32.2 \mathrm{~Hz}, 1 \mathrm{C}\right), 38.10 ; 37.8 ; 37.6 ; 37.3 ; 37.0 ; 36.7\left(\mathrm{sex}, \mathrm{C}^{*} \mathrm{H}\left(\mathrm{CF}_{3}\right)\right.$ of TFP between two $\mathrm{CH}_{2}$ groups, $\left.{ }^{2} J_{\mathrm{CF}}=27.17 \mathrm{~Hz}, 1 \mathrm{C}\right], 35.56 ; 33.29$ ( d, $\mathrm{CH}_{2}$ of TFP-I, 1C), $27.70 ; 27.51 ; 27.29 ; 27.10$ ( two d of $\mathrm{CH}_{2},{ }^{2} J_{\mathrm{CF}}=19.1 \mathrm{~Hz}, 1 \mathrm{C}$ ), 19.53-18.55; $17.23-$ 16.30 (d of q (tr/er) $\left.* \mathrm{CH}\left(\mathrm{CF}_{3}\right) \mathrm{I},{ }^{2} J_{\mathrm{CF}}=29.2 \mathrm{~Hz}, 1 \mathrm{C}\right)$.

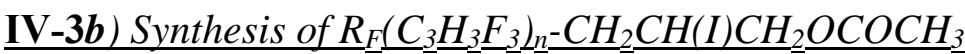

In a $250 \mathrm{ml}$ three-necked round-bottom flask equipped with a double condenser and a thermometer were introduced a certain amount of monoadduct or diadduct produced in the previous reaction and a 1.2-fold excess of allyl acetate. Then, the mixture was heated up to $82{ }^{\circ} \mathrm{C}$ and stirred. When the temperature reached $80{ }^{\circ} \mathrm{C}, \mathrm{AIBN}\left(C_{0}=0.015\right.$ to 0.050$)$ was introduced step-wise for $10 \mathrm{~h}$ - reaction time. No exothermicity was 
observed. After $10 \mathrm{~h}$, the reaction was stopped; the crude product was cooled to room temperature, filtered and analyzed by GC. The reaction mixture was distilled to purify the iodo-acetate. The obtained characteristics are shown in Table 3.

\section{Characteristics of the products}

Run 3, Table 3; $n-\mathrm{C}_{6} \mathrm{~F}_{13}\left(\mathrm{C}_{3} \mathrm{H}_{3} \mathrm{~F}_{3}\right)-\mathrm{CH}_{2} \mathrm{CH}(\mathrm{I}) \mathrm{CH}_{2} \mathrm{OCOCH}_{3}$ 6,6,7,7,8,8,9,9,10,10,11,11,11-tridecafluoro-2-iodo-4-(trifluoromethyl)undecyl acetate

${ }^{19}$ F NMR $\left(\mathrm{CDCl}_{3}\right) \delta$, ppm: -81.9 and from -111 to -127 (the same chemical shifts as for Run 1) -71.39 and -72.59 are assigned to $\mathbf{C F}_{\mathbf{3}}$ of TFP in both diastereoisomers.

${ }^{1} \mathbf{H}$ NMR $\left(\mathrm{CDCl}_{3}\right) \delta$, ppm: $2.05\left(\mathrm{~s}, \mathrm{CH}_{3}, 3 \mathrm{H}\right), 2.4-2.6\left(\mathrm{~m}, \mathrm{C}^{*} \mathbf{H}\left(\mathrm{CF}_{3}\right), 1 \mathrm{H}\right), 2.8-3.0(\mathrm{~m}$, $\left.\mathrm{C}_{6} \mathrm{~F}_{13} \mathrm{CH}_{2}, 2 \mathrm{H}\right), 4.1-4.3\left(\mathrm{~m}, \mathrm{CH}_{2} \mathrm{OCOCH}_{3}, 2 \mathrm{H}\right), 4.4-4.5$ (m, C*H(I), 1H).

Run 9, Table 3; $\left(\mathrm{CF}_{3}\right)_{2} \mathrm{CF}\left(\mathrm{C}_{3} \mathrm{H}_{3} \mathrm{~F}_{3}\right) \mathrm{CH}_{2} \mathrm{CH}(\mathrm{I}) \mathrm{CH}_{2} \mathrm{OCOCH}_{3}$ 6,7,7,7-tetrafluoroheptyl-2-iodo-4,6-bis(trifluoromethyl) acetate

${ }^{19} \mathbf{F}$ NMR $\left(\mathrm{CDCl}_{3}\right) \delta$, ppm: -71.2 and $-72.3\left(\mathrm{CF}_{3}\right.$ of TFP,(normal and reverse adducts), $3 \mathrm{~F}),-77.3$ and $-77.6\left(\mathrm{~m},\left(\mathrm{CF}_{3}\right)_{2} \mathrm{C}(\mathrm{F}),{ }^{3} J_{\mathrm{FF}}=69.5 \mathrm{~Hz}, 6 \mathrm{~F}\right),-185.8,-187.1(\mathrm{~m}, \mathrm{C}(\mathbf{F}), 1 \mathrm{~F})$.

${ }^{1} \mathbf{H}$ NMR $\left(\mathrm{CDCl}_{3}\right) \delta$, ppm : $2.02\left(\mathrm{~s}, \mathrm{CH}_{3}, 3 \mathrm{H}\right), 2.1-2.2\left(\mathrm{~m}, \mathrm{CH}_{2} \mathrm{CH}(\mathrm{I}), 2 \mathrm{H}\right), 2.25-2.60$ (m, $\left.\mathrm{C}(\mathrm{F}) \mathrm{CH}_{2}, 2 \mathrm{H}\right), 2.8-3.1\left(\mathrm{~m},{ }^{*} \mathrm{CH}\left(\mathrm{CF}_{3}\right), 1 \mathrm{H}\right), 4.1-4.25\left(\mathrm{~m}, \mathrm{CH}_{2} \mathrm{OCO}, 2 \mathrm{H}\right), 4.3-4.5$ ( $\mathrm{m}, \mathrm{CH}(\mathrm{I}), 1 \mathrm{H})$.

Run 4, Table 3; n- $\mathrm{C}_{6} \mathrm{~F}_{13}\left(\mathrm{C}_{3} \mathrm{H}_{3} \mathrm{~F}_{3}\right)_{2}-\mathrm{CH}_{2} \mathrm{CH}(\mathrm{I}) \mathrm{CH}_{2} \mathrm{OCOCH}_{3}$ 8,8,9,9,10,10,11,11,12,12,13,13,13-tridecafluoro-2-iodo-4,6-bis(trifluoromethyl) tridecanyl acetate

${ }^{19} \mathbf{F}$ NMR $\left(\mathrm{CDCl}_{3}\right) \delta$, ppm: - 70 to -73 (complex system, $2 \mathrm{xCF}_{\mathbf{3}}$ of TFP, $\left.6 \mathrm{~F}\right),-81.6(\mathrm{~s}$, $\mathrm{CF}_{3}$ of $n-\mathrm{C}_{6} \mathrm{~F}_{13}, 3 \mathrm{~F}$ ), -111.8 to -127 (the same assignments as those in Run $1,{ }^{19} \mathrm{~F}$ NMR). ${ }^{1} \mathbf{H}$ NMR $\left(\mathrm{CDCl}_{3}\right) \delta$, ppm: $2.05\left(\mathrm{~s}, \mathrm{CH}_{3}\right.$ from $\left.\mathrm{OCOCH}_{3}, 3 \mathrm{H}\right), 2.3\left({ }^{*} \mathrm{C}-\mathrm{CH}_{2}{ }^{*} \mathrm{C}, 2 \mathrm{H}\right)$, $2.24\left(\mathrm{CH}_{2} \mathrm{CH}(\mathrm{I}), 2 \mathrm{H}\right), 2.5\left({ }^{*} \mathrm{CH}\left(\mathrm{CF}_{3}\right)\right.$ overlapping with 2.58 ppm signal, $\left.1 \mathrm{H}\right), 2.58$ 
$\left(\mathrm{m}, \mathrm{R}_{\mathrm{F}}-\mathrm{CH}_{2}, 2 \mathrm{H}\right), 2.8\left(\mathrm{~m},{ }^{*} \mathrm{CH}\left(\mathrm{CF}_{3}\right), 1 \mathrm{H}\right), 4.2\left(\mathrm{~m}, \mathrm{C}^{*} \mathbf{H}(\mathrm{I}), 1 \mathrm{H}\right), 4.4(\mathrm{~m}$, ester $\left.\mathrm{CH}_{2} \mathrm{OCOCH}_{3}, 2 \mathrm{H}\right)$.

Run 10, Table 3; $\left(\mathrm{CF}_{3}\right)_{2} \mathrm{CF}\left(\mathrm{C}_{3} \mathrm{H}_{3} \mathrm{~F}_{3}\right)_{2} \mathrm{CH}_{2} \mathrm{CH}(\mathrm{I}) \mathrm{CH}_{2} \mathrm{OCOCH}_{3}$ 8,9,9,9-tetrafluoro-2-iodo-4,6,8-tris(trifluoromethyl)nonyl acetate

${ }^{19} \mathbf{F}$ NMR $\left(\mathrm{CDCl}_{3}\right) \delta$, ppm : no signal at -67 ( no reverse product) ; -70.5 to -72.77 ( $\mathrm{m}$, $2 \mathrm{xCF} \mathbf{F}_{3}$ of TFP, $\left.6 \mathrm{~F}\right),-77.2$ to $78.75\left(\mathrm{~m},\left(\mathrm{CF}_{3}\right)_{2}, 6 \mathrm{~F}\right) ;-186.4,-187.14,-187.73(\mathrm{t}, \mathrm{C}(\mathbf{F})$, $1 \mathrm{~F})$.

${ }^{1} \mathbf{H}$ NMR $\left(\mathrm{CDCl}_{3}, \mathrm{ppm}\right) \delta: 1.6-1.9\left(\mathrm{~m},{ }^{*} \mathrm{C}-\mathrm{CH}_{2^{-}}{ }^{*} \mathrm{C}, 2 \mathrm{H}\right) ; 2.02-2.25,\left(\mathrm{CH}_{3}\right.$ in $\mathrm{CH}_{3} \mathrm{OCO}$, $3 \mathrm{H}), 2.25-2.4\left(\mathrm{CH}_{2}-\mathrm{CHI}, 2 \mathrm{H}\right) ; 2.3-2.5\left(\mathrm{R}_{\mathrm{F}}-\mathrm{CH}_{2}, 2 \mathrm{H}\right) ; 2.6-3.0\left({ }^{*} \mathrm{CH}\left(\mathrm{CF}_{3}\right), 1 \mathrm{H}\right), 4.2(\mathrm{~m}$, $1 \mathrm{H}$ of $\mathrm{CH}(\mathrm{I})+1 \mathrm{H}$ of $\left.* \mathrm{CH}\left(\mathrm{CF}_{3}\right)\right), 4.4\left(\mathrm{~m}\right.$, ester $\left.\mathrm{CH}_{2} \mathrm{OCOCH}_{3}, 2 \mathrm{H}\right)$.

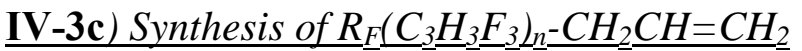

$\mathrm{Zn}$ dust was activated with $1.2 \mathrm{~g}$ of a mixture of acetic acid/acetic anhydride (1/1), 40 $\mathrm{ml}$ of $\mathrm{CH}_{3} \mathrm{OH}$ was added and they were introduced into $250 \mathrm{ml}$ two-neck round- bottom flask with a reverse condenser and magnetic stirrer. The temperature was increased to $65{ }^{\circ} \mathrm{C}$ while stirring. The iodo-acetate prepared in Run 3, Table 3 (60.05 g, $\left.0.094 \mathrm{~mol}\right)$ in $30 \mathrm{ml} \mathrm{MeOH}$ was added dropwise under reflux to a $\mathrm{Zn}$ slurry within $3 \mathrm{~h}$ with vigorous stirring and then the reaction mixture was stirred for $2 \mathrm{~h}$. A colourless product was obtained. The $\mathrm{Zn}$ complex was filtered off, the filtrate was diluted with $\mathrm{CH}_{2} \mathrm{Cl}_{2}(1 / 1$ vol.) and washed with $10 \% \mathrm{HCl}$ aqueous solution $(100 \mathrm{ml})$ and washed again with distilled water. The organic phase was added dropwise to anhydrous $\mathrm{MgSO}_{4}$ under stirring to eliminate traces of water, filtered and twice distilled (Table 3).

\section{Characteristics of the products}

Run 5, Table 3; $n-\mathrm{C}_{6} \mathrm{~F}_{13}\left(\mathrm{C}_{3} \mathrm{H}_{3} \mathrm{~F}_{3}\right)-\mathrm{CH}_{2} \mathrm{CH}=\mathrm{CH}_{2}$

6,6,7,7,8,8,9,9,10,10,11,11,11-tridecafluoro-4-(trifluoromethyl)undec-1-ene 
${ }^{19} \mathbf{F}$ NMR $\left(\mathrm{CDCl}_{3}\right) \delta$, ppm: The same chemical shifts as those of $n-\mathrm{C}_{6} \mathrm{~F}_{13}\left(\mathrm{C}_{3} \mathrm{H}_{3} \mathrm{~F}_{3}\right)-$ $\mathrm{CH}_{2} \mathrm{CH}(\mathrm{I}) \mathrm{CH}_{2} \mathrm{OCOCH}_{3}$ except for the signal centred at -113 ppm which is simpler and gives only one peak at -72.0 (one diastereoisomer).

${ }^{1} \mathbf{H}$ NMR $\left(\mathrm{CDCl}_{3}\right) \delta$, ppm: 2.2-2.6 (m, $n-\mathrm{C}_{6} \mathrm{~F}_{13} \mathrm{CH}$ and $\left.\mathrm{CH}_{2}-\mathrm{CH}, 4 \mathrm{H}\right), 2.6-2.8\left(\mathrm{~m},{ }^{*} \mathrm{CH}\right.$ $\left.\left(\mathrm{CF}_{3}\right), 1 \mathrm{H}\right)$, 5.1-5.4 (m, $\left.\mathrm{CH}_{2}=, 2 \mathrm{H}\right)$, 5.6-5.9 $(\mathrm{m}, \mathrm{CH}=, 1 \mathrm{H})$.

${ }^{13} \mathbf{C ~ N M R}\left(\mathrm{CDCl}_{3}\right) \delta$, ppm: 132.18 (132.08) (d (2 diastereoisomers), $\left.\mathbf{C H}=, 1 \mathrm{C}\right), 131.03$ ; 128.26, $125.48,122.71$ (q, $\mathbf{C F}_{3}$ of TFP $\left.,{ }^{1} J_{\mathrm{CF}}=279.0 \mathrm{~Hz}, 1 \mathrm{C}\right), 120.4-104.9$ (complex system, $\left.n-\mathbf{C}_{6} \mathrm{~F}_{13}, 6 \mathrm{C}\right), 118.8-118.7\left(\mathrm{~d}, \mathrm{CH}_{2}=, 1 \mathrm{C}\right), 36.68-35.86\left(\mathrm{q},{ }^{*} \mathbf{C H}\left(\mathrm{CF}_{3}\right),{ }^{2} J_{\mathrm{CF}}=27.2\right.$ $\mathrm{Hz}, 1 \mathrm{C}), 32.68\left(\mathrm{~s}, \mathbf{C H}_{2}, 1 \mathrm{C}\right), 28.18-27.75\left(\mathrm{t}, \mathbf{C H}_{2} \mathrm{R}_{\mathrm{F}},{ }^{2} J_{\mathrm{CF}}=21.13 \mathrm{~Hz}, 1 \mathrm{C}\right)$.

Run 11, Table 3; $\left(\mathrm{CF}_{3}\right)_{2} \mathrm{CF}\left(\mathrm{C}_{3} \mathrm{H}_{3} \mathrm{~F}_{3}\right) \mathrm{CH}_{2} \mathrm{CH}=\mathrm{CH}_{2}$

6,7,7,7-tetrafluoro-4,6-bis(trifluoromethyl)hept-1-ene

${ }^{19} \mathbf{F}$ NMR $\left(\mathrm{CDCl}_{3}\right) \delta$, ppm: $-72.2\left(\mathrm{CF}_{\mathbf{3}}\right.$ of TFP, 3F $),-78.8$ and $-78.4\left(\mathrm{dt},\left(\mathrm{CF}_{3}\right)_{2}, 6 \mathrm{~F}\right)$, $-187.1(\mathrm{~m}, \mathrm{C}(\mathbf{F}), 1 \mathrm{~F})$.

${ }^{1} \mathbf{H}$ NMR $\left(\mathrm{CDCl}_{3}\right) \delta$, ppm: 2.2-2.6 (m, $\left.\mathrm{CH}_{2} \mathrm{CH}=\mathrm{CH}_{2}+\mathrm{C}(\mathrm{F}) \mathrm{CH}_{2}, 4 \mathrm{H}\right)$, 2.6-3.0 (m, $\left.{ }^{*} \mathrm{CH}\left(\mathrm{CF}_{3}\right), 1 \mathrm{H}\right)$, 5.05-5.4 (m, $\left.\mathrm{CH}=\mathrm{CH}_{2}, 2 \mathrm{H}\right)$, 5.6-5.9 (m, $\left.\mathrm{CH}_{2}=\mathrm{CH}, 1 \mathrm{H}\right)$.

${ }^{13} \mathbf{C}$ NMR $\left(\mathrm{CDCl}_{3}\right) \delta$, ppm: $132.2(=\mathbf{C H}, 1 \mathrm{C}), 131.1 ; 128.3 ; 125.5 ; 122.8\left(\mathrm{q}, \mathbf{C F}_{3}\right.$ of TFP, $\left.{ }^{1} J_{\mathrm{CF}}=279.7 \mathrm{~Hz}, 1 \mathrm{C}\right), 125.0 ; 122.1 ; 119.0 ; 116.5\left(\mathrm{q}\right.$ of $\mathrm{d}\left(\mathrm{CF}_{3}\right)_{2},{ }^{1} J_{\mathrm{CF}}=284.7 \mathrm{~Hz}$, $\left.\left.{ }^{2} J_{\mathrm{CF}}=27.2 \mathrm{~Hz}, 6 \mathrm{C}\right), \quad 119.4\left(\mathrm{~s}, \mathrm{CH}=\mathrm{CH}_{2}\right), 1 \mathrm{C}\right), 90\left(\mathrm{~d}\right.$ of sept, $\mathbf{C}(\mathrm{F}),{ }^{1} J_{\mathrm{CF}}=206.3 \mathrm{~Hz}$, $\left.{ }^{2} J_{\mathrm{CF}}=32.0 \mathrm{~Hz}, 1 \mathrm{C}\right), 37.1\left(\mathrm{q}, * \mathbf{C H}\left(\mathrm{CF}_{3}\right),{ }^{2} J_{\mathrm{CF}}=27.2 \mathrm{~Hz}, 1 \mathrm{C}\right), 33.27\left(\mathrm{q}, \mathrm{CH}_{2}=\mathrm{CHCH}_{2}\right.$, $\left.{ }^{3} \mathrm{~J}_{\mathrm{CF}}=2.0 \mathrm{~Hz}, 1 \mathrm{C}\right), 25.5\left(\mathrm{~d}, \mathrm{C}(\mathrm{F}) \mathrm{CH}_{2},{ }^{2} J_{\mathrm{CF}}=19.1 \mathrm{~Hz}, 1 \mathrm{C}\right)$.

Run 6, Table 3; $n-\mathrm{C}_{6} \mathrm{~F}_{13}\left(\mathrm{C}_{3} \mathrm{H}_{3} \mathrm{~F}_{3}\right)_{2}-\mathrm{CH}_{2} \mathrm{CH}=\mathrm{CH}_{2}$ 8,8,9,9,10,10,11,11,12,12,13,13,13-tridecafluoro-4,6-bis(trifluoromethyl)tridec-1-ene 
${ }^{19} \mathbf{F}$ NMR $\left(\mathrm{CDCl}_{3}\right) \delta$, ppm: $-71.9\left(\mathrm{~d}, \mathrm{CF}_{\mathbf{3}}\right.$ adjacent to allyl, 3F), $-72.6\left(\mathrm{~d}, \mathrm{CF}_{\mathbf{3}}\right.$ of TFP to the $\mathrm{C}_{6} \mathrm{~F}_{13}$ side, $3 \mathrm{~F}$ ), -82.0 ( $\mathrm{t}, \alpha \mathrm{CF}_{3}$ of $n-\mathrm{C}_{6} \mathrm{~F}_{13}, 3 \mathrm{~F}$ ), the group of signals from -112 to 127 ppm belongs to $\mathrm{C}_{5} \mathbf{F}_{\mathbf{1 0}}$ as in Run 1 .

${ }^{1} \mathbf{H}$ NMR $\left(\mathrm{CDCl}_{3}\right) \delta$, ppm: $1.6-1.8$ and $50 \%$ from 1.8-2.2 (qn, $\left.{ }^{*} \mathrm{C}-\mathrm{CH}_{2-} \mathrm{C}^{*}, 2 \mathrm{H}\right), 1.8-2.2$ (m, $\mathrm{CH}_{2} \mathrm{CH}=\mathrm{CH}_{2}, 2 \mathrm{H}$ ), 2.2-2.6 (m, overlap of $2 \mathrm{H}$ from $\mathrm{CH}_{2}$ of $\mathrm{R}_{\mathrm{F}} \mathrm{CH}_{2}$ and $1 \mathrm{H}$ from $\left.{ }^{*} \mathrm{CH}\left(\mathrm{CF}_{3}\right)\right), 2.8\left(\mathrm{~m},{ }^{*} \mathrm{CH}\left(\mathrm{CF}_{3}\right), 1 \mathrm{H}\right), 5.10-5.18\left(\mathrm{~m}, \mathrm{CH}_{2}=, 2 \mathrm{H}\right), 5.58-5.84(\mathrm{~m}, \mathrm{CH}=$, $1 \mathrm{H})$.

${ }^{13} \mathbf{C}$ NMR $\left(\mathrm{CDCl}_{3}\right) \delta$, ppm: 133.03 (132.81) (d, (diastereoisomers), $\left.\mathbf{C H}=, 1 \mathrm{C}\right), 131.73$ (131.61) ; 128.96 (128.83); 126.18 (126.06) ; 123.41 (123.28) (q of d (diastereoisomers) $\mathrm{CF}_{3}$ of TFP on the side of $\left.\mathrm{R}_{\mathrm{F}},{ }^{1} J_{\mathrm{CF}}=279.2 \mathrm{~Hz}, 1 \mathrm{C}\right), 131.10$ (130.94); 128.32 (128.16); 125.55 (125.39); 122.78 (122.62) (q of $\mathrm{t}$ (diastereoisomers), $\mathrm{CF}_{3}$ of TFP on the side of allyl, $\left.{ }^{1} J_{\mathrm{CF}}=279.01 \mathrm{~Hz},{ }^{2} J_{\mathrm{CF}}=31.5 \mathrm{~Hz}, 1 \mathrm{C}\right), 118.40(118.28)\left(\mathrm{d}, \mathrm{CH}_{2}=, 1 \mathrm{C}\right), \quad 122-105.9$ (complex system of $\left.\mathbf{C}_{6} \mathrm{~F}_{13}, 6 \mathrm{C}\right), 40.46$ ( 40.39) ; 40.20 (40.14) ; $39.95(39.88) ; 39.69$ (39.63) (q of $d$ (diastereoisomers) ${ }^{*} \mathrm{CH}\left(\mathrm{CF}_{3}\right)$ from the side of $\mathrm{R}_{\mathrm{F}},{ }^{2} J_{\mathrm{CF}}=25.8 \mathrm{~Hz}, 1 \mathrm{C}$ ), $35.06 ; 34.80 ; 34.52 ; 34.25 ; 33.98\left(\mathrm{q},{ }^{*} \mathrm{CH}\left(\mathrm{CF}_{3}\right)\right.$ from the side of allyl, ${ }^{2} J_{\mathrm{CF}}=27.25 \mathrm{~Hz}$, 1C), $32.60(32.57) ; 32.22(32.20)\left(\mathrm{CH}_{2}\right.$ adjacent to vinyl, 1C), 30.51; $30.09 ; 29.88(\mathrm{t}$, $\left.\mathrm{R}_{\mathrm{F}} \mathrm{CH}_{2},{ }^{2} J_{\mathrm{CF}}=21.5 \mathrm{~Hz}, 1 \mathrm{C}\right), 27.52\left(\mathrm{~s}, \mathbf{C H}_{2}\right.$ from $\left.* \mathrm{C}-\mathbf{C H}_{2^{-}} * \mathrm{C}, 1 \mathrm{C}\right)$.

Run 12, Table3; $\left(\mathrm{CF}_{3}\right)_{2} \mathrm{CF}\left(\mathrm{C}_{3} \mathrm{H}_{3} \mathrm{~F}_{3}\right)_{2} \mathrm{CH}_{2} \mathrm{CH}=\mathrm{CH}_{2}$

8,9,9,9- tetrafluoro-4,6,8-tris(trifluoromethyl)non-1-ene

${ }^{19} \mathbf{F}$ NMR $\left(\mathrm{CDCl}_{3}\right) \delta$, ppm : -71.7; $-72.2 ;-72.5(\mathrm{t}, 2 \mathrm{x} \mathrm{CF}$ in TFP, 6F), -77.7 to-78.9 $\left(\mathrm{dt},\left(\mathrm{CF}_{3}\right)_{2}, 6 \mathrm{~F}\right),-186.9 ;-187.4(\mathrm{~m}, \mathrm{C}(\mathrm{F}), 1 \mathrm{~F})$.

${ }^{1} \mathbf{H}$ NMR $\left(\mathrm{CDCl}_{3}\right) \delta$, ppm : 1.55-2.2(m, $\mathrm{CH}_{2}$ from $\left.{ }^{*} \mathrm{C}-\mathrm{CH}_{2}-\mathrm{C}^{*}, 2 \mathrm{H}\right), 2.0-2.2(\mathrm{~m}$, allyl $\left.\mathrm{CH}_{2}, 2 \mathrm{H}\right), 2.3-2.5\left(\mathrm{~m}, 2 \mathrm{H}\right.$ of $\mathrm{R}_{\mathrm{F}}-\mathrm{CH}_{2}+25 \%$ of diastereoisomer $* \mathrm{CH}\left(\mathrm{CF}_{3}\right)$ from the 
side of $\left.\mathrm{R}_{\mathrm{F}}\right), 2.9\left(\mathrm{~m}, 1 \mathrm{H}\right.$ of ${ }^{*} \mathrm{CH}\left(\mathrm{CF}_{3}\right)$ from the side of the allyl), $5.20\left(\mathrm{~m}, \mathrm{CH}_{2}=, 2 \mathrm{H}\right)$, $5.7\left(\mathrm{~m}, \mathrm{CH}=\mathrm{CH}_{2}, 1 \mathrm{H}\right)$.

${ }^{13} \mathbf{C}$ NMR $\left(\mathrm{CDCl}_{3}\right) \delta$, ppm : 133.21 (132.89) (d, $\left.\mathrm{CH}_{2}=\mathbf{C H}-, 1 \mathrm{C}\right), 131.76$ (131.61); 128.98 (128.83); 126.20 (126.05); 123.43 (123.28) ( q, $\mathbf{C F}_{3}$ of TFP on the side of $\mathrm{R}_{\mathrm{F}}$ $\left.{ }^{1} J_{\mathrm{CF}}=279.7 \mathrm{~Hz}, 1 \mathrm{C}\right), \quad 131.18$ (131.00); 128.40 (128.22); 125.62 (125.45); 122.84 (122.67) (q, $\mathbf{C F}_{3}$ of TFP adjacent to allyl, $\left.{ }^{1} J_{\mathrm{CF}}=279.7 \mathrm{~Hz}, 1 \mathrm{C}\right), 125.10(125.06) ; 124.82$ (124.79); 122.26 (122.23); 121.98 (121.95); 116.59 (116.55); 116.30 (116.26) (two qq, $\left.\left(\mathrm{CF}_{3}\right)_{2},{ }^{1} J_{\mathrm{CF}}=285.7 \mathrm{~Hz},{ }^{2} J_{\mathrm{CF}}=28.17 \mathrm{~Hz}, 2 \mathrm{C}\right), 188.29(118.24)\left(\mathrm{d}, \mathrm{CH}=\mathbf{C H}_{2}, 1 \mathrm{C}\right)$, $92.74-88.77$ (d of sept, $-\mathbf{C}(\mathrm{F})-,{ }^{1} J_{\mathrm{CF}}=206.25 \mathrm{~Hz},{ }^{2} J_{\mathrm{CF}}=32.2 \mathrm{~Hz}, 1 \mathrm{C}$ ), 40.37-39.38 (qn, $\left.{ }^{*} \mathbf{C H}\left(\mathrm{CF}_{3}\right),{ }^{2} J_{\mathrm{CF}}=25.15 \mathrm{~Hz}, 1 \mathrm{C}\right), 35.85-34.68$ (qn of d, ${ }^{*} \mathbf{C H}\left(\mathrm{CF}_{3}\right)$ adjacent to allyl, $\left.{ }^{2} J_{\mathrm{CF}}=27.16 \mathrm{~Hz}, 1 \mathrm{C}\right), 32.78-32.75\left(\mathrm{~d}, \mathrm{CH}_{2}\right.$ adjacent to vinyl, $\left.1 \mathrm{C}\right), 32.10 ; 32.08 ; 31.91$ (t, $\mathbf{C H}_{2}$ between $\left.2 * \mathrm{C}, 1 \mathrm{C}\right), 28.94,27.70$ (two d $\left.\mathbf{C H}_{2}-\mathrm{R}_{\mathrm{F}},{ }^{2} \mathrm{~J}_{\mathrm{CF}}=19.12 \mathrm{~Hz}, 1 \mathrm{C}\right)$.

Acknowledgements: The authors thank the Great Lakes (now Chemtura) Company (USA) for sponsoring this work and for the gifts of TFP and $i-C_{3} F_{7} I$, and Elf Atochem for the gift of $\mathrm{C}_{6} \mathrm{~F}_{13} \mathrm{I}$.

\section{REFERENCES}

1. Haszeldine R.N., J. Chem.Soc. 1951, 2495.

2. Haszeldine R.N., J. Chem. Soc.1952, 2504.

3. Haszeldine R.N., Steele B.R., J. Chem. Soc.1953, 1199.

4. Low H.C., Tedder J. M., Walton J. C., J. Chem. Soc., Faraday Trans. 1976, 72, 1300.

5. Kostov G.K., Ameduri B., Brandstadter S.M., US Pat.60/99284 (to Chemtura) (2007). 
6. Haszeldine R.N., Newlands M. J, Plumb J. B., J. Chem. Soc., 1965, 2101.

7. a) Block H.D., German Patent DE 2,514,640 (to Bayer) (1976); b) Kostov G.K., Ameduri B., Brandstadter S. M., J. Fluorine Chem. 2007, 128, 910.

8.Chen J., Zhang Y.-F., Zheng X., Vij A., Wingate D., Meng D., White K., Kirchmeier R.L., Shreeve J.M., Inorg. Chem. 1996, 35, 1590.

9. Terentev A.B., Pastushenko E.V., Kruglov D.E., Rybininia T.A., Izv. Akad. Nauk SSSR, Ser. Khim. 1992, 2768.

10. Harran G., Sharp D.W.A., J. Chem. Soc. Perkin Trans. 1972, 34.

11. Feast W.J., Gimeno M., Khosravi E., Polymer, 2003, 44, 6111.

12. Ikonnikov N.S., Lamova N. I., Terentev A.B., Iz. Akad. Nauk SSSR, Ser. Khim. 1988, 117.

13. a) Zamyslov R. A., Shostenko A.G., Dobrov I.V., Myshkin V.E., Zh. Org. Khim., 1980, 16, 897; b) Shostenko A.G., Dobrov I .V., Chertorizhskii A.V., Khim. Prom. 1983, 339; c) Zamyslov R. A., Zh. Vses. Khim. Obshch. Im. D.I.Mendeleeva 1986, 31, 589; d) Zamyslov R.A., Shostenko A.G., Dobrov I.V., Tarasova N.P., Kinet. Katal. 1987, 28, 977

14. Terentev A.B., Vasileva T. T., Ind. Chem. Library 1995; 7, 180.

15.Vasileva T. T., Fokina I. A., Vitt S. V., Dostovalova V. I., Izv. Akad. Nauk SSSR, Ser. Khim. 1990, 8, 1807

16. Keim W., Raffeis G.H., Kurth D., J. Fluorine Chem. 1990, 48, 229.

17. a) Gasanov R.G., Vasileva T.T., Gapusenko S. I., Kinet. Katal. 1991, 32,1466; b) Vasileva T.T., Fokina I.A., Vitt S .V., Izv. Akad. Nauk SSSR, Ser. Khim. 1991,1384.

18.Vasileva T. T., Kochetkova V. A., Dostovalova V. I., Nelyubin B. V., Freidlina R. K., Izv. Akad. Nauk SSSR, Ser. Khim. 1989,2558. 
19.Vasileva T. T., Kochetkova V. A., Nelyubin B. V., Dostovalova V. I., Freidlina R. K., Izv. Akad. Nauk SSSR, Ser. Khim .1987, 808.

20. a) Balague J., Ameduri B., Boutevin B., Caporiccio G., J. Fluorine Chem. 1995, 70, 215; b) Gelin M.P., Ameduri B., J. Polym. Sci., Part A: Polym.Chem. 2003, 41, 160;

c) Ameduri B., Ladaviere C., Boutevin B., Delolme F., Macromolecules 2004, 37, 7602.

21. Ameduri B., Boutevin B.: Well-Architectured Fluoropolymers: Synthesis, Properties and Applications, Chapter 1, pp 1-99, Elsevier, Amsterdam, 2004.

22. Pennsalt Chem.Corp. US Pat. 868494 (1956).

23. Pennsalt Chem.Corp. GB Pat. 927403 (1963).

24. Rondestvedt C.S. Jr., Fr. Patent 152177 (to Du Pont) (1968).

25. Jap. Pat. 49066611 (1974).

26.Cirkva V., Ameduri B., Boutevin B., Kvicala J., Paleta O., J.Fluorine Chem. 1995, $74,97$.

27. Ameduri B., Boutevin B., Kostov G.K., Petrova P., J. Fluorine Chem. 1998, 92, 69.

28. Ameduri B., Boutevin B., Nouiri M., Talbi M., J. Fluorine Chem. 1995, 74, 191. 


\section{TABLE CAPTIONS}

Table 1.Telomerization of 3,3,3-trifluoroprop-1-ene with different chain-transfer agents (or telogens) and initiators

Table 2. Radical telomerization of 3,3,3-trifluoroprop-1-ene with $\mathrm{R}_{\mathrm{F}} \mathrm{I}^{\mathrm{a}}$ as a telogen at different reaction conditions

Table 3.Main reaction products and their characteristics 
Table 1. Telomerization of 3,3,3-trifluoroprop-1-ene with different chain-transfer agents (or telogens) and initiators (experimental conditions and results)

\begin{tabular}{|c|c|c|c|}
\hline Telogen & Initiator & Telomers & Ref. \\
\hline $\mathrm{CF}_{3} \mathrm{I}$ & UV/5 days & $\mathrm{CF}_{3}\left[\mathrm{CH}_{2} \mathrm{CH}\left(\mathrm{CF}_{3}\right)\right]_{\mathrm{n}} \mathrm{I} \quad \mathrm{n}=1,2$ & 2 \\
\hline $\mathrm{CF}_{3} \mathrm{I}$ & $225^{\circ} \mathrm{C} / 36 \mathrm{~h}$ & $\mathrm{CF}_{3}\left[\mathrm{CH}_{2} \mathrm{CH}\left(\mathrm{CF}_{3}\right)\right]_{\mathrm{n}} \mathrm{I} \quad \mathrm{n}=1-3$ & $2-3$ \\
\hline $\mathrm{CF}_{3} \mathrm{I}$ & $\mathrm{UV} /$ various $\mathrm{T}$ & $\begin{array}{l}\text { Normal and reverse monoadducts } \\
\text { small amounts of } n=2\end{array}$ & 4 \\
\hline $\mathrm{IC}_{6} \mathrm{~F}_{12} \mathrm{I}$ & $(t-\mathrm{BuO})_{2} / 143{ }^{\circ} \mathrm{C}$ & $\left\{\mathrm{I}\left[\mathrm{CH}_{2}-\mathrm{CH}\left(\mathrm{CF}_{3}\right)\right]_{\mathrm{n}} \mathrm{C}_{3} \mathrm{~F}_{6}\right\}_{2} \quad \mathrm{n}=1-3$ & 5 \\
\hline $\mathrm{Cl}_{3} \mathrm{Si}-\mathrm{H}$ & UV & $\mathrm{Cl}_{3} \mathrm{Si}\left[\mathrm{CH}_{2} \mathrm{CH}\left(\mathrm{CF}_{3}\right)\right]_{\mathrm{n}} \mathrm{H} \quad \mathrm{n}=1,2$ & 6 \\
\hline$\left(\mathrm{C}_{2} \mathrm{H}_{5} \mathrm{O}\right)_{2} \mathrm{P}(\mathrm{O}) \mathrm{H}$ & $(t-\mathrm{BuO})_{2 / 130}{ }^{\circ} \mathrm{C}$ & $\left(\mathrm{C}_{2} \mathrm{H}_{5} \mathrm{O}\right)_{2} \mathrm{P}(\mathrm{O}) \mathrm{CH}_{2} \mathrm{CH}_{2} \mathrm{CF}_{3} \quad(39 \%)$ & $7 \mathrm{a}$ \\
\hline$\left(\mathrm{C}_{2} \mathrm{H}_{5} \mathrm{O}\right)_{2} \mathrm{P}(\mathrm{O}) \mathrm{H}$ & $(t-\mathrm{BuO})_{2 /} 140^{\circ} \mathrm{C}$ & $\mathrm{H}(\mathrm{TFP})_{n} \mathrm{P}(\mathrm{O})\left(\mathrm{OC}_{2} \mathrm{H}_{5}\right)_{2} \quad \mathrm{n}=1-4$ & $7 \mathrm{~b}$ \\
\hline THF & DTBP $/ 140{ }^{\circ} \mathrm{C}$ & monoadduct $(48 \%)$ & 8 \\
\hline $\begin{array}{l}\text { 2-Me-1,3- } \\
\text { dioxolane }\end{array}$ & $\mathrm{Fe}(\mathrm{CO})_{5}$ & 2-Me-2,4-bis(TFP)-dioxolane & 9 \\
\hline $\mathrm{CH}_{3} \mathrm{SSCH}_{3}$ & UV & $\mathrm{CH}_{3} \mathrm{SCH}_{2} \mathrm{CH}\left(\mathrm{CF}_{3}\right) \mathrm{SCH}_{3}$ & 10 \\
\hline $\mathrm{HBr}$ & UV & $\mathrm{CF}_{3} \mathrm{CH}_{2} \mathrm{CH}_{2} \mathrm{Br}$ & 2 \\
\hline Cyclopentadiene & $180^{\circ} \mathrm{C} / 72 \mathrm{~h}$ & Exo/endo $=62: 38$ & 11 \\
\hline $\mathrm{CH}_{3} \mathrm{OCOCH}\left(\mathrm{CH}_{3}\right)_{2}$ & peroxides & $\mathrm{CH}_{3} \mathrm{OCOC}\left(\mathrm{CH}_{3}\right)_{2}\left[\mathrm{CH}_{2} \mathrm{CH}\left(\mathrm{CF}_{3}\right)\right]_{\mathrm{n}} \mathrm{H}$ & 12 \\
\hline$\left(\mathrm{CH}_{3}\right)_{2} \mathrm{CHOH}$ & $\gamma$-rays $\left(T<90{ }^{\circ} \mathrm{C}\right)$ & $\begin{array}{c}\left(\mathrm{CH}_{3}\right)_{2} \mathrm{C}(\mathrm{OH})\left[\mathrm{CH}_{2} \mathrm{CH}\left(\mathrm{CF}_{3}\right)\right]_{\mathrm{n}} \mathrm{H} \\
\mathrm{n}=1,2\end{array}$ & 13 \\
\hline $\mathrm{C}_{6} \mathrm{H}_{5} \mathrm{CH}_{2}-\mathrm{Cl}$ & $\mathrm{Fe}(\mathrm{CO})_{5}$ & $\begin{array}{l}\mathrm{C}_{6} \mathrm{H}_{5} \mathrm{CHX}\left[\mathrm{CH}_{2} \mathrm{CH}\left(\mathrm{CF}_{3}\right)\right]_{n} \mathrm{Y} \\
\mathrm{n}=1,2 \quad \mathrm{X}=\mathrm{Cl}, \mathrm{H} \quad \mathrm{Y}=\mathrm{H}, \mathrm{Cl}\end{array}$ & 14 \\
\hline $\mathrm{CCl}_{4}$ & $\mathrm{Fe}(\mathrm{CO})_{5}$ & $\mathrm{Cl}_{3} \mathrm{C}\left[\mathrm{CH}_{2} \mathrm{CH}\left(\mathrm{CF}_{3}\right)\right]_{\mathrm{n}} \mathrm{Cl}, \mathrm{n}=1-3$ & 15 \\
\hline $\mathrm{CCl}_{4}$ & $\mathrm{CuCl}_{2} / \mathrm{LiCl}$ & $\mathrm{Cl}_{3} \mathrm{C}\left[\mathrm{CH}_{2} \mathrm{CH}\left(\mathrm{CF}_{3}\right)\right]_{\mathrm{n}} \mathrm{Cl}, \mathrm{n}=1-7$ & 16 \\
\hline $\mathrm{C}_{6} \mathrm{H}_{5} \mathrm{CH}_{2} \mathrm{Br}$ & $\mathrm{Fe}(\mathrm{CO})_{5}$ & $\begin{array}{c}\mathrm{C}_{6} \mathrm{H}_{5} \mathrm{CHX}\left[\mathrm{CH}_{2} \mathrm{CH}\left(\mathrm{CF}_{3}\right)\right]_{\mathrm{n}} \mathrm{Y} \\
\mathrm{n}=1-2 ; \mathrm{X}=\mathrm{Br}, \mathrm{H} ; \mathrm{Y}=\mathrm{H}, \mathrm{Br} .\end{array}$ & 17 \\
\hline $\mathrm{CHBr}_{3}$ & $\mathrm{Fe}(\mathrm{CO})_{5} / \mathrm{DMF}$ & $\mathrm{Br}_{2} \mathrm{CH}\left[\mathrm{CH}_{2} \mathrm{CH}\left(\mathrm{CF}_{3}\right)\right]_{\mathrm{n}} \mathrm{Br} \quad \mathrm{n}=1-3$ & 18 \\
\hline $\mathrm{Br}_{2} \mathrm{CHBr}$ & DBP* & $\begin{array}{l}\mathrm{XCBr} 2\left[\mathrm{CH}_{2} \mathrm{CH}\left(\mathrm{CF}_{3}\right)\right]_{\mathrm{n}} \mathrm{Y} \\
\mathrm{Y}=\mathrm{X}=\mathrm{H} \text { or } \mathrm{Br} \quad \mathrm{n}=1,2\end{array}$ & 18 \\
\hline $\mathrm{BrCH}_{2} \mathrm{Br}$ & $\mathrm{Fe}(\mathrm{CO})_{5}$ & $\mathrm{BrCH}_{2}\left[\mathrm{CH}_{2} \mathrm{CH}\left(\mathrm{CF}_{3}\right)\right]_{\mathrm{n}} \mathrm{Br} \quad \mathrm{n}=1,2$ & 18 \\
\hline $\mathrm{CBr}_{4}$ & DBP* & $\mathrm{Br}_{3} \mathrm{C}\left[\mathrm{CH}_{2} \mathrm{CH}\left(\mathrm{CF}_{3}\right)\right]_{\mathrm{n}} \mathrm{Br} \quad \mathrm{n}=1-3$ & 19 \\
\hline
\end{tabular}

* dibenzoyl peroxide 
Table 2.Radical telomerization of 3,3,3-trifluoroprop-1-ene with $\mathrm{R}_{\mathrm{F}} \mathrm{I}^{\mathrm{a}}$ as a telogen at different reaction conditions (batch operation) ${ }^{\mathrm{b}}$

\begin{tabular}{|c|c|c|c|c|c|c|c|c|c|c|c|}
\hline \multirow[t]{2}{*}{ Run } & \multirow[t]{2}{*}{ Initiator } & \multirow[t]{2}{*}{$R_{0}$} & \multirow[t]{2}{*}{$C_{0}$} & \multirow{2}{*}{$\begin{array}{r}T \\
\left({ }^{\circ} \mathrm{C}\right)\end{array}$} & \multirow{2}{*}{$\begin{array}{l}t_{r} \\
(\mathrm{~h})\end{array}$} & \multirow{2}{*}{\multicolumn{2}{|c|}{$\begin{array}{c}P(\text { bar }) \\
\max \min \end{array}$}} & \multirow{2}{*}{$\begin{array}{c}\text { TFP } \\
\text { conv. } \\
(\%)\end{array}$} & \multicolumn{3}{|c|}{$\%$ by $\mathrm{GC}^{\mathrm{c}}$} \\
\hline & & & & & & & & & $\mathrm{R}_{\mathrm{F}} \mathrm{I}$ & $\mathrm{A}, 1$ & $\mathrm{~A}, 2^{\mathrm{d}}$ \\
\hline 1 & Thermal & 0.25 & - & 160 & 20 & 39 & 34 & 36.8 & 52.8 & 26.2 & 21.0 \\
\hline 2 & Thermal & 0.50 & - & 160 & 20 & 22 & 17 & 79.2 & 27.6 & 51.9 & 20.5 \\
\hline 3 & Thermal & 0.50 & - & 180 & 22 & 30 & 11 & 73.4 & 2.4 & 65.9 & 31.2 \\
\hline $4^{e}$ & Perkadox16s & 0.50 & 0.03 & 62 & 20 & 7 & 5 & 79.2 & 23.8 & 35.4 & 40.8 \\
\hline 5 & AIBN & 0.50 & 0.03 & 82 & 18 & 10 & 7 & 79.2 & 17.4 & 38.8 & 42 \\
\hline 6 & Trigonox101 & 0.50 & 0.03 & 134 & 6 & 16 & 0.6 & 89.6 & 3.7 & 19.1 & 63.8 \\
\hline 7 & DTBP & 0.50 & 0.03 & 140 & 6 & 17 & 0.2 & 97.9 & 3.7 & 19.0 & 63.8 \\
\hline 8 & DTBP & 0.50 & 0.03 & 143 & 4 & 19 & 0.8 & 94.3 & 9.6 & 21.1 & 66.6 \\
\hline 9 & DTBP & 1.40 & 0.03 & 140 & 4 & 13 & 1.1 & 95.2 & 22.5 & 54.4 & 15.7 \\
\hline 10 & DTBP & 0.40 & 0.03 & 140 & 4 & 25 & 2 & 96.8 & 2.9 & 3.7 & 47.4 \\
\hline 11 & DTBP & 0.50 & 0.03 & 140 & 4 & 22 & 2 & 98.1 & 3.3 & 10.15 & 57.9 \\
\hline 12 & DTBP & 0.75 & 0.03 & 145 & 4 & 20 & 3.0 & 93.8 & 6.8 & 34.1 & 49.0 \\
\hline 13 & DTBP & 1.20 & 0.03 & 150 & 4 & 20 & 5.0 & 90.0 & 14.9 & 46.3 & 33.4 \\
\hline 14 & DTBP & 1.40 & 0.03 & 150 & 4 & 21 & 3.5 & 95.0 & 12.6 & 54.1 & 28.6 \\
\hline 15 & DTBP & 1.50 & 0.03 & 150 & 4 & 19 & 5.0 & 95.0 & 24.6 & 43.9 & 28.3 \\
\hline 16 & UV & 1.40 & - & 30 & 24 & - & - & 75.2 & 27.8 & 38.2 & 21.6 \\
\hline $17^{\mathrm{f}}$ & $\mathrm{Fe}^{3+} /$ Benzoin & 1.40 & 0.3 & 140 & 48 & - & - & 48.5 & 39.8 & 32.5 & 18.4 \\
\hline
\end{tabular}
a) $\mathrm{R}_{\mathrm{F}}=n-\mathrm{C}_{6} \mathrm{~F}_{13}$ ( Runs $\left.1-9 ; 16,17\right)$ and $\left(\mathrm{CF}_{3}\right)_{2} \mathrm{CF}$ (Runs 10-15)
b) $R_{0}=\left[\mathrm{R}_{\mathrm{F}} \mathrm{I}\right]_{0} /[\mathrm{TFP}]_{0} ; C_{0}=[\mathrm{In}]_{0} /[\mathrm{TFP}]$ (In stands for initiator)
c) The remaining part contained higher TFP telomers $(n>2)$
d) A,1 and A,2 stand for $\mathrm{R}_{\mathrm{F}}\left(\mathrm{C}_{3} \mathrm{H}_{3} \mathrm{~F}_{3}\right)_{1} \mathrm{I}$ and $\mathrm{R}_{\mathrm{F}}\left(\mathrm{C}_{3} \mathrm{H}_{3} \mathrm{~F}_{3}\right)_{2} \mathrm{I}$, respectively
e) Perkadox 16s- Bis(4-tert-butylcyclohexyl)peroxydicarbonate; purity $95 \%$.
f) $\mathrm{FeCl}_{3} / \mathrm{C}_{6} \mathrm{H}_{5} \mathrm{CH}(\mathrm{OH}) \mathrm{COC}_{6} \mathrm{H}_{5}(1 / 1 \mathrm{~mol})$ 
Table 3.Main reaction products and their characteristics

\begin{tabular}{|c|c|c|c|c|}
\hline \multirow[t]{2}{*}{ Run } & \multirow[t]{2}{*}{ Product } & \multirow{2}{*}{$\begin{array}{l}\mathrm{RT}^{*} \\
(\min )\end{array}$} & \multicolumn{2}{|c|}{ b.p. } \\
\hline & & & ${ }^{\circ} \mathrm{C}$ & $\begin{array}{l}\text { Pressure } \\
(\mathrm{mm} \mathrm{Hg})\end{array}$ \\
\hline 1 & $\mathrm{n}-\mathrm{C}_{6} \mathrm{~F}_{13}\left(\mathrm{C}_{3} \mathrm{H}_{3} \mathrm{~F}_{3}\right)-\mathrm{I}(\mathrm{A}, 1)$ & 3.6 & $\begin{array}{l}24-26 \\
71-73\end{array}$ & $\begin{array}{c}0.4 \\
18-25\end{array}$ \\
\hline 2 & $n-\mathrm{C}_{6} \mathrm{~F}_{13}\left(\mathrm{C}_{3} \mathrm{H}_{3} \mathrm{~F}_{3}\right)_{2}-\mathrm{I}(\mathrm{A}, 2)$ & 5.5 & $\begin{array}{c}29-31 \\
100-105\end{array}$ & $\begin{array}{c}0.2 \\
18-25\end{array}$ \\
\hline 3 & $n-\mathrm{C}_{6} \mathrm{~F}_{13}\left(\mathrm{C}_{3} \mathrm{H}_{3} \mathrm{~F}_{3}\right)-\mathrm{CH}_{2} \mathrm{CH}(\mathrm{I}) \mathrm{CH}_{2} \mathrm{OCOCH}_{3}$ & 11.5 & $70-72$ & 0.1 \\
\hline 4 & $n-\mathrm{C}_{6} \mathrm{~F}_{13}\left(\mathrm{C}_{3} \mathrm{H}_{3} \mathrm{~F}_{3}\right)_{2}-\mathrm{CH}_{2} \mathrm{CH}(\mathrm{I}) \mathrm{CH}_{2} \mathrm{OCOCH}_{3}$ & 13.4 & $110-115$ & 0.05 \\
\hline 5 & $n-\mathrm{C}_{6} \mathrm{~F}_{13}\left(\mathrm{C}_{3} \mathrm{H}_{3} \mathrm{~F}_{3}\right)-\mathrm{CH}_{2} \mathrm{CH}=\mathrm{CH}_{2}$ & 3.2 & $\begin{array}{c}68-70 \\
105-108\end{array}$ & $\begin{array}{c}18-25 \\
\text { normal }\end{array}$ \\
\hline 6 & $n-\mathrm{C}_{6} \mathrm{~F}_{13}\left(\mathrm{C}_{3} \mathrm{H}_{3} \mathrm{~F}_{3}\right)_{2}-\mathrm{CH}_{2} \mathrm{CH}=\mathrm{CH} 2$ & 5.3 & $100-103$ & $18-25$ \\
\hline 7 & $\left(\mathrm{CF}_{3}\right)_{2} \mathrm{C}(\mathrm{F}) \mathrm{C}_{3} \mathrm{H}_{3} \mathrm{~F}_{3} \mathrm{I}$ & 1.5 & $100-110$ & normal \\
\hline 8 & $\left(\mathrm{CF}_{3}\right)_{2} \mathrm{C}(\mathrm{F})\left(\mathrm{C}_{3} \mathrm{H}_{3} \mathrm{~F}_{3}\right)_{2}-\mathrm{I}$ & 3.2 & $65-70$ & $18-25$ \\
\hline 9 & $\left(\mathrm{CF}_{3}\right)_{2} \mathrm{C}(\mathrm{F})\left(\mathrm{C}_{3} \mathrm{H}_{3} \mathrm{~F}_{3}\right) \mathrm{CH}_{2} \mathrm{CH}(\mathrm{I}) \mathrm{CH}_{2} \mathrm{OCOCH}_{3}$ & $8.2-8.9$ & $\begin{array}{c}115-120 \\
65-70\end{array}$ & $\begin{array}{c}18-25 \\
1\end{array}$ \\
\hline 10 & $\left(\mathrm{CF}_{3}\right)_{2} \mathrm{C}(\mathrm{F})\left(\mathrm{C}_{3} \mathrm{H}_{3} \mathrm{~F}_{3}\right)_{2} \mathrm{CH}_{2} \mathrm{CH}(\mathrm{I}) \mathrm{CH}_{2} \mathrm{OCOCH}_{3}$ & $10.8-11.1$ & $78-84$ & 0.1 \\
\hline 11 & $\left(\mathrm{CF}_{3}\right)_{2} \mathrm{C}(\mathrm{F})\left(\mathrm{C}_{3} \mathrm{H}_{3} \mathrm{~F}_{3}\right) \mathrm{CH}_{2} \mathrm{CH}=\mathrm{CH}_{2}$ & $1.3-1.5$ & $105-110$ & normal \\
\hline 12 & $\left(\mathrm{CF}_{3}\right)_{2} \mathrm{C}(\mathrm{F})\left(\mathrm{C}_{3} \mathrm{H}_{3} \mathrm{~F}_{3}\right)_{2} \mathrm{CH}_{2} \mathrm{CH}=\mathrm{CH}_{2}$ & $2.9-3.1$ & $63-64$ & $18-25$ \\
\hline
\end{tabular}

*RT stands for retention time; GC analysis: column OV1 (3\% silicone grease on

Chromosorb G); 2 m length, $1 / 8^{\prime \prime}$ diameter, $50-200{ }^{\circ} \mathrm{C}$. 


\section{SCHEME CAPTIONS}

Scheme 1.Radical telomerization of 3, 3, 3-trifluoroprop-1-ene (TFP) with perfluoroalkyl iodide

Scheme 2.Mechanism of radical telomerization of 3,3,3-trifluoroprop-1-ene (TFP) with perfluoroalkyl iodide $\left(\mathrm{R}_{\mathrm{F}} \mathrm{I}\right)$

Scheme 3.Radical addition of TFP telomers onto allyl acetate

Scheme 4.Synthesis of fluorinated allylic monomers $\mathbf{C}, \mathbf{n}$ by deiododeacetatization of B,n 


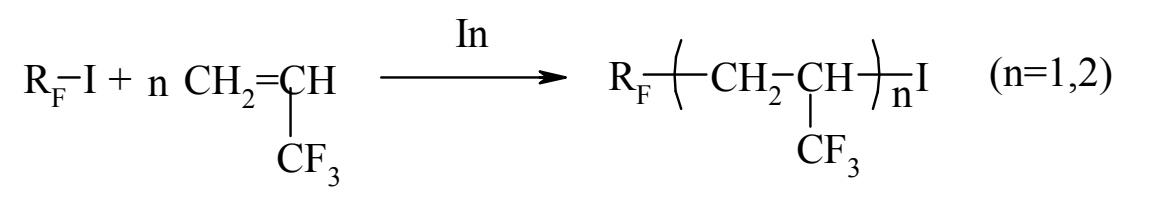

\begin{abstract}
A,n
Scheme1. Radical telomerization of 3,3,3-trifluoroprop-1-ene (TFP) with perfluoroalkyl iodide
\end{abstract}




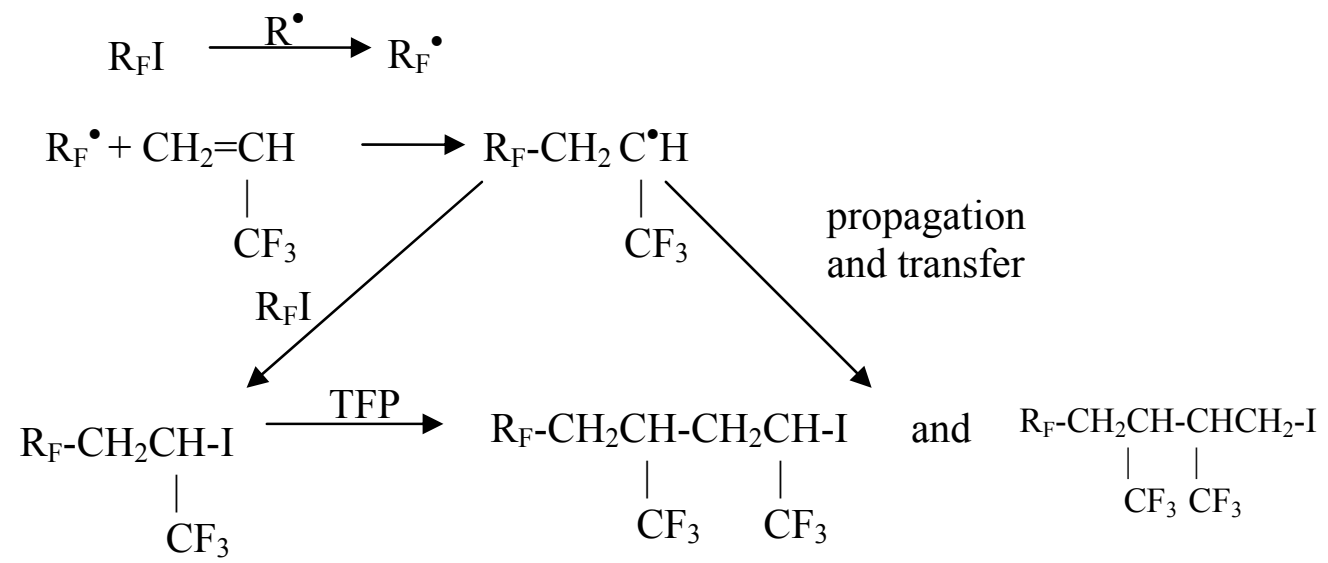

normal addition

reverse addition

Scheme 2. Mechanism of radical telomerization of 3,3,3-trifluoroprop-1-ene (TFP) with perfluoroalkyl iodide $\left(\mathrm{R}_{\mathrm{F}} \mathrm{I}\right)$ 


$$
\mathbf{A , n}+\mathrm{CH}_{2}=\mathrm{CHCH}_{2} \mathrm{OAc} \frac{\mathrm{AIBN}}{82^{\circ} \mathrm{C}, 10 \mathrm{~h}} \underset{\mathrm{F}}{\longrightarrow}-\mathrm{R}_{\mathrm{F}} \underset{\mathbf{B}, \mathbf{n}}{\mathrm{C}}
$$

Scheme 3. Radical addition of TFP telomers onto allyl acetate 


$$
\text { B,n } \underset{\text { reflux, } 5 \mathrm{~h}}{\stackrel{\mathrm{Zn} / \mathrm{CH}_{3} \mathrm{OH}}{\longrightarrow}} \mathrm{CH}_{2}=\mathrm{CH}-\mathrm{CH}_{2}\left(\underset{\substack{\mathrm{CF}_{3} \\ \mathbf{C , n}}}{\left.\mathrm{CH}-\mathrm{CH}_{2}\right)}\right)_{\mathrm{n}} \mathrm{R}_{\mathrm{F}}
$$

Scheme 4.Synthesis of fluorinated allylic monomers $\mathbf{C , n}$ by deiododeacetatization of B,n 


\section{FIGURE CAPTIONS}

Figure 1. ${ }^{19} \mathrm{~F}$ NMR spectrum (in $\left.\mathrm{CDCl}_{3}\right)$ of $n-\mathrm{C}_{6} \mathrm{~F}_{13}\left(\mathrm{C}_{3} \mathrm{H}_{3} \mathrm{~F}_{3}\right) \mathrm{I}$ monoadduct

Figure 2. DEPT ${ }^{13} \mathrm{C}$ NMR spectrum (in $\left.\mathrm{CDCl}_{3}\right)$ of $\left(\mathrm{CF}_{3}\right)_{2} \mathrm{CF}\left(\mathrm{C}_{3} \mathrm{H}_{3} \mathrm{~F}_{3}\right) \mathrm{I}$ monoadduct

Figure 3. ${ }^{1} \mathrm{H}$ NMR spectrum (in $\left.\mathrm{CDCl}_{3}\right)$ of $\left(\mathrm{CF}_{3}\right)_{2} \mathrm{CF}\left[\mathrm{CH}_{2} \mathrm{CH}\left(\mathrm{CF}_{3}\right)\right] \mathrm{CH}_{2} \mathrm{CH}=\mathrm{CH}_{2}$. 


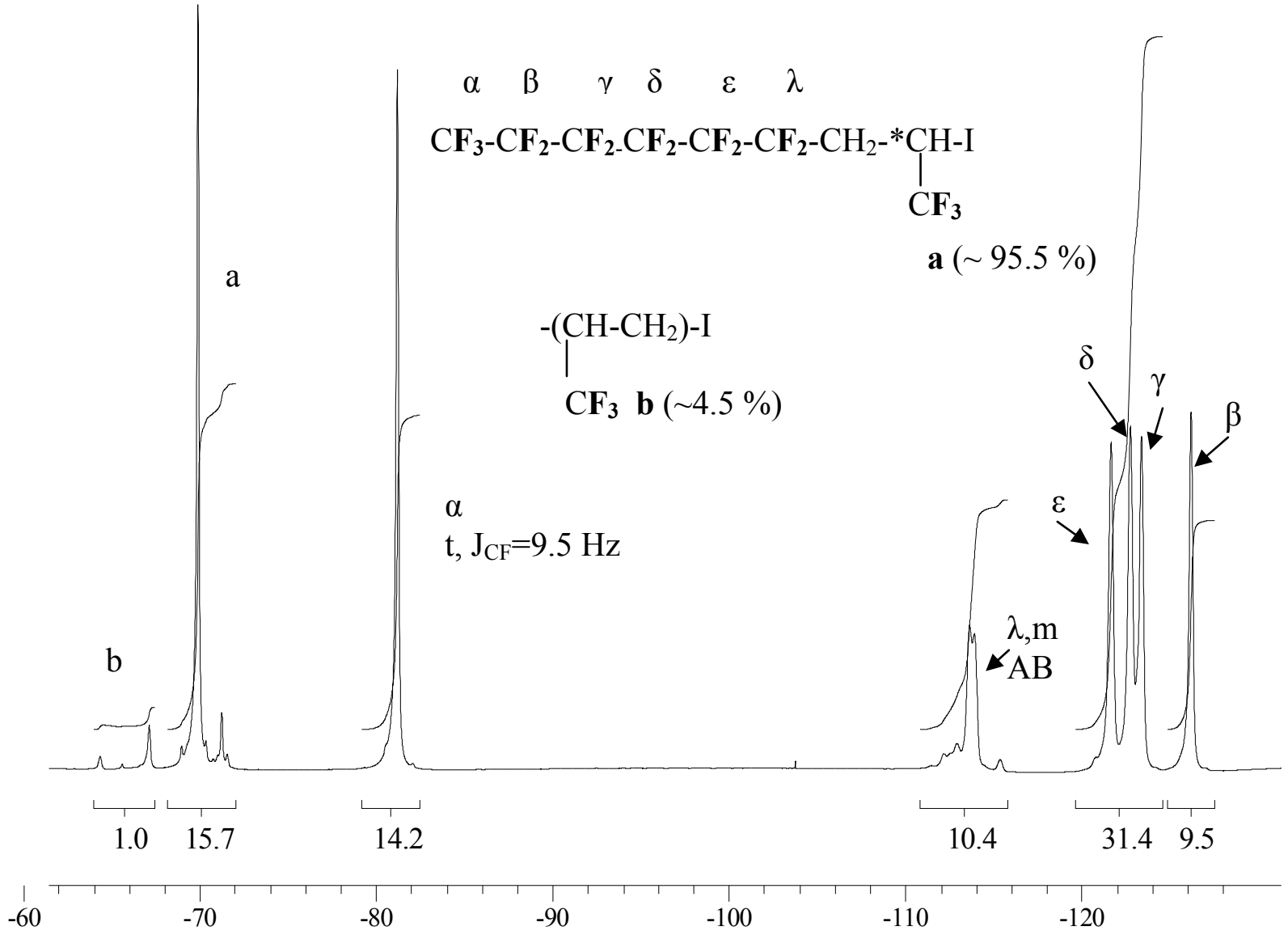

Figure 1. ${ }^{19} \mathrm{~F}$ NMR spectrum (in $\left.\mathrm{CDCl}_{3}\right)$ of $n-\mathrm{C}_{6} \mathrm{~F}_{13}\left(\mathrm{C}_{3} \mathrm{H}_{3} \mathrm{~F}_{3}\right) \mathrm{I}$ monoadduct. 


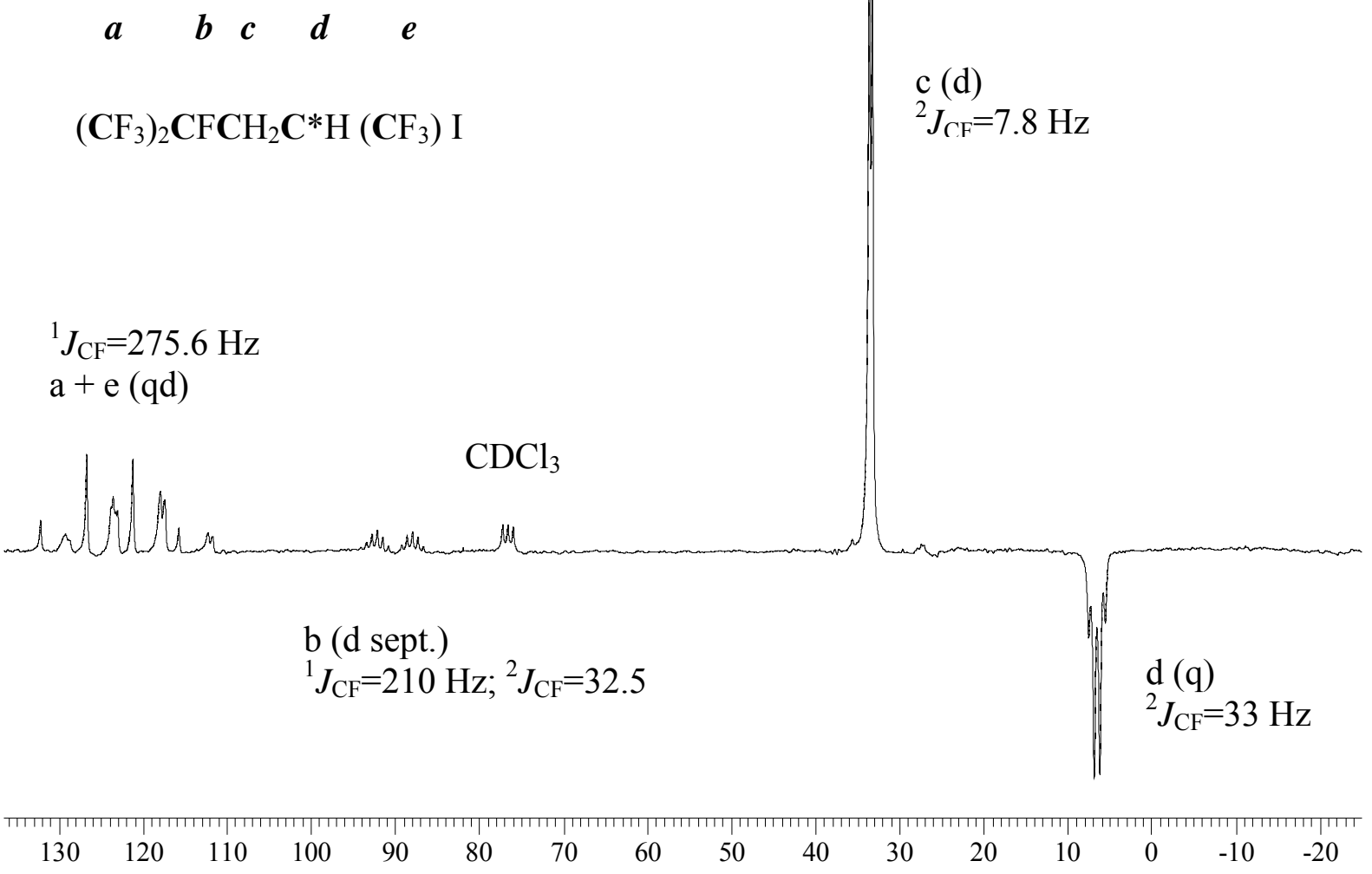

Figure 2. DEPT ${ }^{13} \mathrm{C}$ NMR spectrum (in $\left.\mathrm{CDCl}_{3}\right)$ of $\left(\mathrm{CF}_{3}\right)_{2} \mathrm{CF}\left(\mathrm{C}_{3} \mathrm{H}_{3} \mathrm{~F}_{3}\right) \mathrm{I}$ monoadduct. 


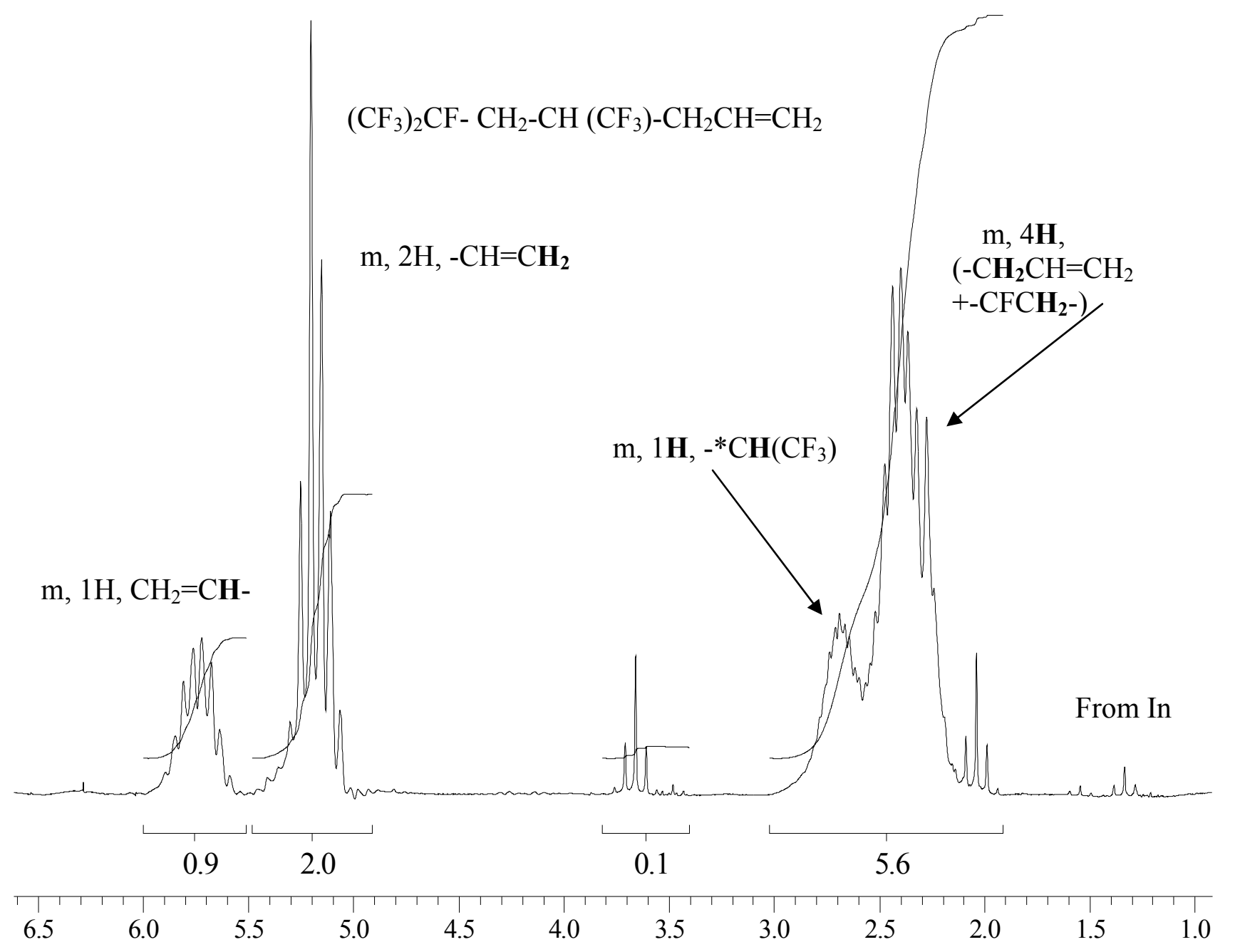

Figure 3. ${ }^{1} \mathrm{H}$ NMR spectrum (in $\left.\mathrm{CDCl}_{3}\right)$ of $\left(\mathrm{CF}_{3}\right)_{2} \mathrm{CF}-\mathrm{CH}_{2}-\mathrm{CH}\left(\mathrm{CF}_{3}\right)-\mathrm{CH}_{2} \mathrm{CH}=\mathrm{CH}_{2}$ 


\section{Graphical Abstract}

\section{TELOMERIZATION OF 3, 3, 3-TRIFLUOROPROP-1-ENE AND FUNCTIONALIZATION OF ITS TELOMERS}

Telomerization of 3,3,3-trifluoroprop-1-ene (TFP) with linear $\left(n-\mathrm{C}_{6} \mathrm{~F}_{13} \mathrm{I}\right)$ or branched $\left[\left(\mathrm{CF}_{3}\right)_{2} \mathrm{CFI}\right]$ perfluoroalkyl iodides led to $\mathbf{A}, \mathbf{n}$ telomers which were chemically changed into their allyl derivatives, as follows:

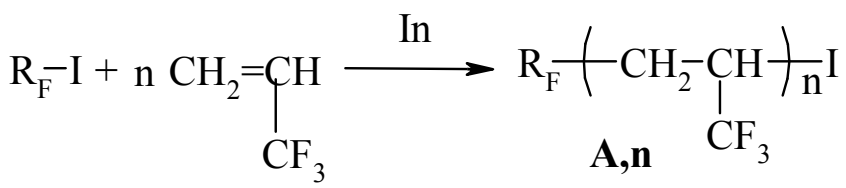

1. allyl acetate

2. $\mathrm{Zn} / \mathrm{MeOH}$

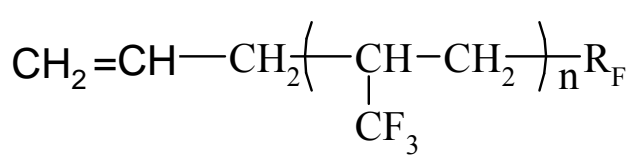

